\title{
Natural History and Conservation of the Greenland Whale, or Bowhead, in the Northwest Atlantic
}

\author{
K.J. FINLEY ${ }^{1}$
}

(Received 25 May 1999; accepted in revised form 4 August 2000)

\begin{abstract}
One of the longest-living mammals, the Greenland whale or bowhead (Balaena mysticetus) is specialized to filter small crustaceans, especially Calanus copepods, from barren Arctic seas. Brought to near extinction by commercial whaling, the North Atlantic 'meta-population' remains at less than 5\% of its former abundance, and none of its three constituent stocks has shown demonstrable recovery during the last century. Two of these stocks, the Baffin Bay and Hudson Bay populations, occur in coastal waters of the Eastern Canadian Arctic during summer. Each of these two stocks numbers in the low hundreds and exists in isolated groups segregated by age and sex, showing strong fidelity to essential habitats. A skewed age distribution, predation by killer whales (Orcinus orca), hunting, net entanglement, tourism, climate change, habitat loss, and inbreeding suppression are some of the factors that may affect the bowhead's recovery. We need local and historical knowledge to understand the bowhead's natural history. Together with scientific data, such knowledge is also useful in evaluating the status of the species and prescribing a management plan. A recovery plan must employ the precautionary principle, both within the international 'meta-population' context and at the sub-population level; it must take a historical view and seek to protect abandoned habitats. Canada has conducted whaling activities that violate international agreements and diminish the effectiveness of the International Whaling Commission.

Key words: Greenland whale, bowhead whale, Balaena mysticetus, biology, conservation, management, traditional knowledge

RÉSUMÉ. La baleine boréale ou baleine franche (Balaena mysticetus), l'un des mammifères qui vit le plus longtemps, est spécialisée pour filtrer les petits crustacés, des copépodes Calanus pour la plupart, vivant dans les mers arctiques peu peuplées. Amenée au bord de l'extinction par la chasse commerciale à la baleine, la «métapopulation» de l'Atlantique Nord se maintient à moins de $5 \mathrm{p}$. cent de son abondance passée, et aucun des trois stocks qui la composent n'a montré un rétablissement ferme au cours du siècle dernier. Deux de ces stocks, la population de la baie de Baffin et celle de la baie d'Hudson, se trouvent en été dans les eaux côtières de l'Arctique canadien oriental. Chacun d'eux comprend quelques centaines d'individus, répartis en groupes isolés selon l'âge et le sexe, qui démontrent une fidélité marquée pour les habitats essentiels à leur survie. Une asymétrie de la distribution par âge, la prédation par les épaulards (Orcinus orca), la chasse, l'enchevêtrement dans les filets, le tourisme, le changement climatique, la perte d'habitat et la dépression consanguine sont au nombre des facteurs qui pourraient influencer le rétablissement de l'espèce. Le savoir local et le savoir historique sont tous deux nécessaires pour comprendre l'évolution naturelle de la baleine boréale. Couplés aux données scientifiques, ces savoirs sont en outre utiles dans l'évaluation de l'état de l'espèce et la mise sur pied d'un plan de gestion. Un plan de rétablissement doit faire appel au principe de prudence à la fois dans le contexte international de la «métapopulation» et au niveau de la sous-population; il doit adopter une vision historique et chercher à protéger les habitats délaissés. Le Canada a procédé à des activités de chasse à la baleine qui enfreignent les ententes internationales et diminuent l'efficacité de la Commission baleinière internationale.
\end{abstract}

Mots clés: baleine franche, baleine boréale, Balaena mysticetus, biologie, conservation, gestion, savoir traditionnel

Traduit pour la revue Arctic par Nésida Loyer.

\section{INTRODUCTION}

The Greenland whale or bowhead (Balaena mysticetus) engenders superlatives. In the Origin of Species, Charles Darwin (1859:236) stated that the "Greenland Whale is one of the most wonderful animals in the world, and the baleen, or whale-bone, one of its greatest peculiarities." Captain Scoresby, Jr. (1820:449) proclaimed it "The Whale by way of eminence," a claim mocked by Melville (1851:138): "This is Charing Cross; hear ye! good people all,- the Greenland Whale is deposed,- - the great Sperm Whale now reigneth!" Recently American biologists have restored the "deposed" species to eminence, as the quintessential K-strategist (Nerini et al., 1984). Although Yankee whalers made the Greenland whale known as bowhead, it is still known as Greenland whale in most European languages, and as Arviq (Inuktitut and Inuvialuktun), Agkhovik (Iñupiat), Akhgvopik (Yupik), or Ittiv (Chukchi) in various Eskimo languages. The older term Greenland whale is useful to distinguish North Atlantic whales from

${ }^{1} 10232$ Summerset Place, Sidney, British Columbia V8L 4X2, Canada; kjfinley@islandnet.com

(C) The Arctic Institute of North America 
North Pacific bowheads; for brevity, bowhead is used generally in this paper, but Greenland whale is used occasionally to refer specifically to North Atlantic stocks. Similarly, the older term Eskimo refers generally to the dialect groups noted above, but Inuit is used herein and refers specifically to the Inuit of Nunavut, who speak Inuktitut.

Five stocks of bowheads are recognized by the International Whaling Commission (IWC), two in the North Pacific and three in the North Atlantic. All of these were severely reduced by commercial whaling before the turn of the 19th century, and only one of them, the Bering Sea stock, has shown sufficient signs of recovery to permit aboriginal hunting sanctioned by the IWC. The three North Atlantic stocks - the northeastern 'Spitsbergen' stock and the two northwestern stocks of Baffin Bay and Hudson Bay-are considered among the most endangered of baleen whales and have been under some degree of international protection since 1937 (Jonsgård, 1981, 1982; Zeh et al., 1993; IWC, 1982, 1992, 1998). Since 1994, Canada, under the Nunavut Agreement, has sanctioned the taking of single whales from the Baffin Bay and Hudson Bay stocks, and has allocated small quotas for future hunts (DFO, 1996a, b, 1999a, b). This unilateral action has been condemned by the IWC (1996, 1998a, 1999, 2000a).

Captains and 'surgeon-naturalists' with the British whaling industry provided the earliest natural history accounts of the Greenland whale (Scoresby, 1820; Guerin, 1845; Brown, 1868; Gray, 1888, 1926, 1927, 1932). Eschricht and Reinhardt (1866) produced the first major description of the species. Then, until the last quarter of the 20th century, little was written and virtually no research was conducted. Greenland whales were considered too rare to warrant dedicated field studies, and little was known about them until the oil and gas industry began funding surveys in the mid-1970s (McLaren Marex Inc., 1979; Davis and Koski, 1980; McLaren and Davis, 1981, 1983). These surveys and Inuit knowledge led to the Cape Adair migration watches of 1978 and 1979 and to the rediscovery of an important concentration of whales at Isabella Bay in 1979 (Davis and Koski, 1980). Dedicated field studies were initiated at Isabella Bay in 1983 through a World Wildlife Fund initiative (Hummel, 1986; Finley, 1990) and continued until 1997 (Finley, 1998). Studies of the Hudson Bay stock were initiated by the Department of Fisheries and Oceans (DFO) in 1994 (Cosens et al., 1997; Cosens and Innes, 2000), in response to the pending hunt as ratified in the Nunavut Agreement (DIAND, 1993).

This paper is an overview of the natural history and conservation of the species.

\section{DISTRIBUTION AND MOVEMENTS}

The bowhead is a relict species, geographically and evolutionarily. Believed to have arisen in the Northern Hemisphere during the Pliocene (5.5-1.6 million years ago), it is now restricted to high latitudes by its specialized feeding requirements (McLeod et al., 1993). During the last ice age, bowheads occurred in the Gulf of St. Lawrence, and during the climatic optimum (10000-7500 years ago) they roamed more widely in the Canadian Arctic Archipelago, possibly mixing with Bering Sea whales (Bednarski, 1990). Their range has shrunk and expanded with climatic oscillations over the millennia, as well as in recent centuries (Schledermann, 1976, 1996; McCartney and Savelle, 1985; Dyke and Morris, 1990; Savelle and McCartney, 1990, 1991).

Present patterns of distribution and migration are consistent with historical whaling records, although some grounds remain largely vacant (Ross, 1993; Reeves et al., 1983; Fig. 1). Remnant groups, such as the Baffin Bay 'rocknosers,' were protected by ice fields at the periphery of their range until the last steam-powered phase of Scottish whaling (Anderson, 1934; Finley, 1990). "The cetacea have been driven farther and farther away from their old haunts...when [the whale] leaves one region it can be followed to another, and the ice barriers which frightened old whalers no longer provide it protection" (Anonymous, 1874). Only the very extreme limits of the Greenland whale's range, such as the 'nursery' grounds in Prince Regent Inlet or the northern parts of Foxe Basin, remained inaccessible. Strong selection pressure by the whalers makes it probable that these remnant groups, essentially geographically isolated, are derived from a limited founder population. Photographic identification (Heide-Jørgensen and Finley, 1991) and DNA analysis (Maiers et al., 1999) support the view that there are two stocks in the NW Atlantic, as proposed by the IWC $(1992,1998)$.

Bowhead migrations, scheduled by climate-ice dynamics and plankton development, are shorter than those of many baleen whales. Ross (1993) presented a conceptual migration model for North Atlantic stocks, predicated on anti-cyclonic patterns of currents and ice. Possibly because the plankton bloom begins along the wind-induced flaw leads on leeward (i.e., NW) shores, the whales arrive at these edges first in spring. Although some bowheads undertake roughly counterclockwise migrations of Baffin Bay, covering $4000-5000 \mathrm{~km}$, some simply cross Davis Strait, so that the distance between summering and wintering grounds may be less than $500 \mathrm{~km}$ (Heide-Jørgensen and Finley, 1991). Those that winter in Hudson Strait need only make a short migration to summering grounds in northwestern Hudson Bay and Foxe Basin (Reeves et al., 1983).

Migration routes are often restricted to flaw lead systems in spring or to narrow coastal corridors in autumn. In Baffin Bay, spring migration takes place on a broader front than autumn migration, which is narrowly constricted (e.g., less than $2 \mathrm{~km}$ from shore at Cape Adair; Davis and Koski, 1980). Eschricht and Reinhardt (1866:12) noted the "strict regularity" of migrations along the west Greenland coast: "the whale, at least eighty years ago, made its appearance exactly at the same places and at the same seasons as at present." The species shows strong site fidelity, and a large proportion of the population can be observed 


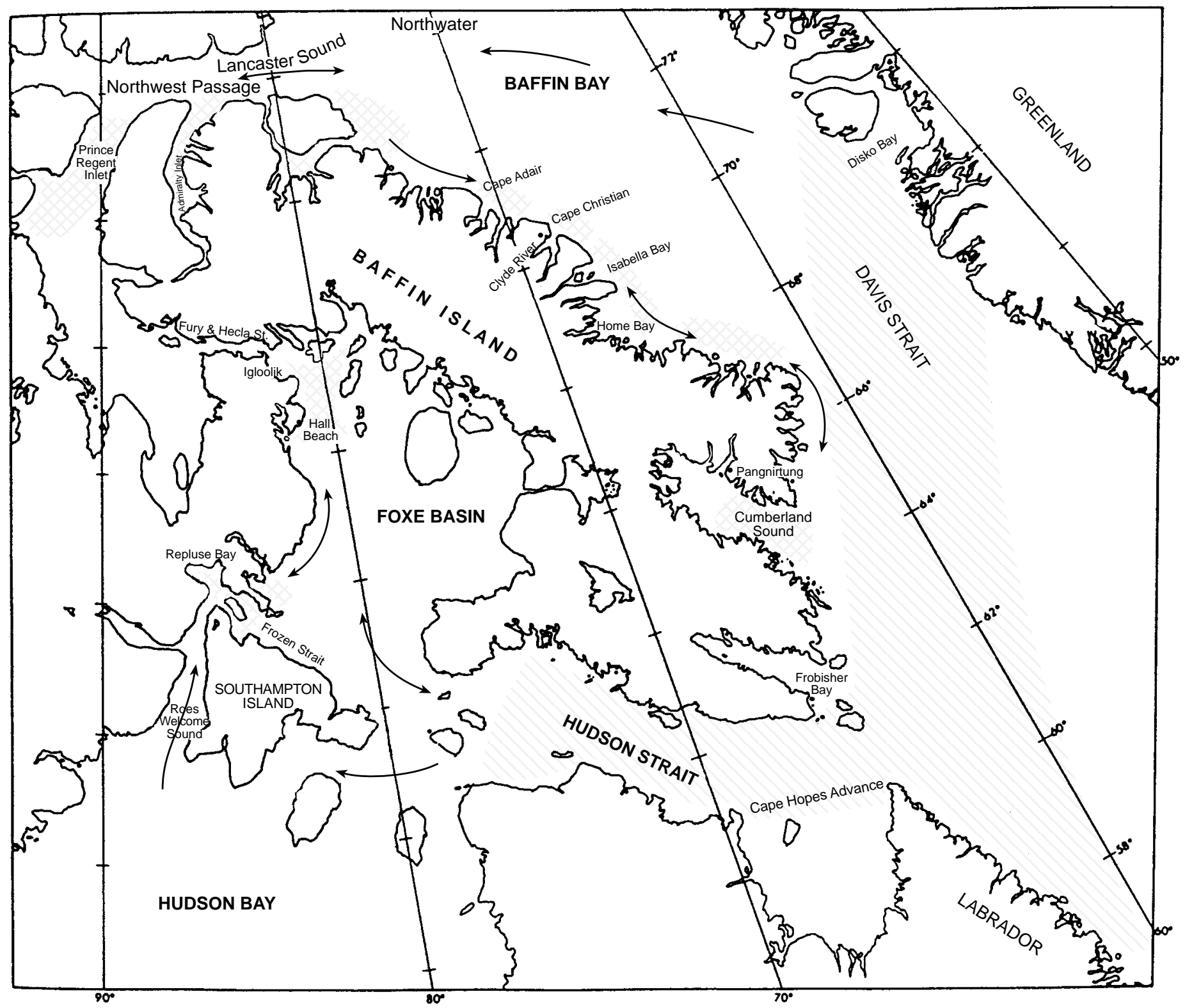

FIG. 1. Winter range (hatching), areas of summer concentration (cross-hatching), and migration routes (arrows) of bowheads in Nunavut.

at a few locations where it congregates or passes by (Finley, 1990; Heide-Jørgensen and Finley, 1991). Reeves et al. (1983) and Moore and Reeves (1993) provide a thorough review. The following brief seasonal overview highlights some features and adds some forgotten anecdotes.

\section{Spring}

In western Davis Strait, bowheads appear at the Cumberland Sound floe edge in April and May; they reach northern Baffin Bay and the Northwest Passage in May and June (Anderson, 1934; Davis and Koski, 1980; LGL, 1983; Holst and Stirling, 1999). Historically, Hudson Bay whales arrived at the floe edges off southwest Southampton Island in May and June, then moved north, following ice breakup, through Roes Welcome Sound, and eventu- ally into Foxe Basin (Anderson, 1934; Ross, 1975, 1993; Reeves et al., 1983; Reeves and Mitchell, 1990). They may also move directly from Hudson Strait into Foxe Basin, appearing at the Igloolik floe edge by late June (Cosens et al., 1997).

\section{Summer}

Bowheads occupy summer grounds from mid-June to early September, concentrating around oceanographic features that create productive feeding habitat. Climate and the life cycles of Calanus copepods strongly influence their distribution, and they tend to segregate according to their feeding abilities.

Some of the Baffin stock move westward through Lancaster Sound in late June and early July to occupy the 
'nursery' grounds of the archipelago until September. Another segment, consisting mostly of adults and adolescents, occupies the 'rocknosing' grounds of NE Baffin Island in late summer-early autumn (Brown, 1868; Davis and Koski, 1980; Finley, 1990). Current local knowledge of distribution patterns is generally consistent with that reported by Anders et al. (1967:26): "Normally the whales can be expected off Cumberland Sound in early spring, occasional whales are spotted in the sound during the summer and they are regularly sighted at Cape Christian and Home Bay in late summer or early fall." In seasons with heavier ice conditions, bowheads tend to remain farther south: in 1983 and 1992, they were observed in Cumberland Sound during August (Finley, 1998). This range variation has prompted speculation that there may be more than one stock of whales in Baffin Bay-Davis Strait (DFO, 1999a, b).

The Hudson Bay stock has always been confined to the northwest region of the bay and northern Foxe Basin (Reeves et al., 1983). Roes Welcome Sound and Repulse Bay were the center of whaling activity. Foxe Basin was too difficult to navigate "on account of numerous shoals and reefs in the known parts, and continuous masses of ice, and these waters were the only portions of the bay where the whales were left undisturbed" (Anderson, 1934:71; italics added). This aggregation still persists in late summer near the mouth of Fury and Hecla Strait (Cosens et al., 1997). Few whales have been seen on their former grounds in Roes Welcome Sound, but they still occur in Repulse Bay and Frozen Strait (Cosens and Innes, 2000).

\section{Autumn}

Migration from above $70^{\circ} \mathrm{N}$ begins in late August and September and occurs casually over the next two to three months, with periods of directed swimming, resting, or feeding. Migration past Cape Adair $\left(71^{\circ} 30^{\prime} \mathrm{N}\right)$, northeast Baffin Island, peaks in late September-early October (Davis and Koski, 1980). Movements slow as the whales feed on the autumn 'rocknosing' grounds (Finley, 1990, 1998). Here they may rejoin the 'rocknosers,' and they eventually reach Cumberland Sound, southeast Baffin Island, in late October and November. At Cape Hopes Advance, Hudson Strait, peak movement occurs in late November (Finley et al., 1982).

\section{Winter}

In winter, bowheads are generally found within the margin of pack ice fields and in polynyas between $60^{\circ}$ and $70^{\circ} \mathrm{N}$. The need for shelter from storms and strong currents, and the need to conserve energy during periods of low food availability, probably define suitable wintering habitat. Anderson (1934:71) stated that the whales remained in Cumberland Sound "along the edge of the new ice until December, after which their position until the next March is unknown." The icebound whalers of the Dee were surprised to see them in January amongst dense pack ice off Baffin Island between $69^{\circ}$ and $70^{\circ} \mathrm{N}$ (Gibb, 1837). In late March 1993, two sightings were recorded in the North Water between $76^{\circ}$ and $77^{\circ} \mathrm{N}$ (Richard et al., 1998). Bowheads winter off Disco Bay, West Greenland (HeideJørgensen and Finley, 1991; Reeves and Heide-Jørgensen, 1996), arriving in late November and December, and remaining until April or May (Born and Heide-Jørgensen, 1983). They also winter in western Hudson Strait (McLaren and Davis, 1981, 1983).

\section{Segregation}

Bowheads are often segregated by size, sex, and reproductive condition during migration and on their summering grounds. Some aspects of population segregation and migration behaviour may be related to predatory pressure from killer whales (Orcinus orca); other aspects relate to diving abilities and habitat partitioning. In Baffin Bay, juveniles precede adults into the North Water and through the Northwest Passage (Lubbock, 1937; Ross, 1985). During late summer and early autumn, cows with calves and juveniles generally occupy the northern 'nursery' grounds, whereas large subadults and adults (males and anestrous females) occupy the 'rocknosing' grounds (Finley, 1990). Thule Eskimo hunters strongly selected juvenile whales $7-10 \mathrm{~m}$ in length, and it is probably no accident that the major Thule archaeological sites are situated on the Greenland whale's nursery grounds (McCartney and Savelle, 1993). A similar pattern of segregation seems to occur in the Hudson Bay stock: cows, calves, and juveniles occupy northern Foxe Basin, while large subadults and adults stay around Repulse Bay and Frozen Strait (Cosens and Blouw, 1999). Segregation patterns are generally but not strictly maintained (Moore and Reeves, 1993; Finley, 1998).

\section{POPULATION SIZE}

All circumpolar stocks of bowheads were subject to intensive commercial whaling by different fleets and were depleted at different times and different rates. North Atlantic stocks were the first to be depleted: Dutch, German, British, and American fleets took at least 120000 bowheads over two and a half centuries (Ross, 1993). Before exploitation, the world population was a minimum 50000 (Woodby and Botkin, 1993); as of the early 1990s, it was estimated at less than 9000, most constituting the Bering Sea stock (Zeh et al., 1993; Raftery and Zeh, 1998). All other stocks number in the tens to low hundreds, most probably less than 5\% of their original size (IWC, 1992).

\section{Baffin Bay Stock}

Dutch and British whaling brought this population to near extinction by the late 19th century (Ross, 1979, 1985, 1993; Mitchell and Reeves, 1981, 1982). At least 28394 whales were taken between 1719 and 1911 (Ross, 1979). 
Mitchell and Reeves (1981) estimated that in 1825, before the height of the British 'North Water' fishery, the population numbered at least 11000 , but noted that it had undoubtedly been much larger, having already been reduced during the Davis Strait fishery. By the 1860s, the population existed in fragments, especially on the 'rocknosing' and 'nursery' grounds, protected by late season ice and the whales' extreme wariness. "The 'rocknosers,' as the migrating whales were termed, from their reputed habit of nosing their way south along the rocks, were due at Cape Kater [Isabella Bay] about September 15 th.... In fall of the year, probably because the sea is very open and free from ice, the whales are very restless and unsettled, so much so that they were difficult to get near and few were killed at this fishing" (Gray, 1927). Baffin whaling experienced a brief resurgence when the Scottish Dundee fleet adopted steam power to exploit the last refuges. Isabella Bay became an important base of operation during this last phase of the industry (Finley, 1990; Finley and Darling, 1990).

On the basis of extensive aerial surveys of NW Baffin Bay and Lancaster Sound, conducted between 1974 and 1979, Davis and Koski (1980:443) stated that it was safe to conclude that the number of bowheads entering the Canadian High Arctic was small- "in the low hundreds at most, and perhaps less than a hundred." With the 'rediscovery' of the Isabella Bay whales, and a better understanding of population segregation and migrations, Finley (1990) estimated the Baffin Bay population at about 250. Zeh et al. (1993), using Finley's photo-identification data, estimated that about 214 whales were present over a two-year period at Isabella Bay (1986-87) and suggested that, along with the northern component, the population could number at least 350. They revised Davis and Koski's estimate to low hundreds at least, rather than low hundreds at most. This may be optimistic (Finley, 2000).

The autumn gathering at Isabella Bay is one of the largest and most consistent aggregations of bowheads known in their North Atlantic range (Finley, 1990; Moore and Reeves, 1993). Systematic monitoring in 11 field seasons between 1983 and 1997 gave an average count of 24 (SD 20) on 80 days with good visibility (Finley, 1998). Much of the variation in distribution and abundance was due to climate and to food abundance, with lowest numbers recorded in El Niño years. Peak numbers $(60-100)$ were recorded in four different years of high copepod production. Given the high degree of site fidelity and the concentration of sightings in these years, Finley (1998) suggested that the high counts represented most of the regional 'rocknoser' group. There was no evident trend in numbers over the 14-year period, although, given the variability and the low reproductive potential of the bowheads, trends would be difficult to detect.

The aerial and shore-based survey efforts in the High Arctic during the late 1970s were huge. The private sector alone covered over 236000 linear $\mathrm{km}$ of potential bowhead habitat between 1974 and 1979, in addition to spending over 100 field days at strategic, shore-based stations (W.R. Koski, LGL Ltd,, pers. comm. 2000). In addition, extensive surveys and ice-based observations were conducted in the same region during the early 1980s (e.g., Finley et al., 1990). These surveys were not designed specifically for bowheads, but they covered their historical range. Although sightings were never compiled and analyzed, my own experience tells me that too few were seen to justify disputing Davis and Koski's (1980) conclusions. These surveys overlapped with the beginning of the Isabella Bay studies, and when the latter ended, I had accumulated 23 years of experience from various viewpoints on the bowhead's range. With this experience, I reiterate Reeves et al.'s (1983:5) conclusion that there "is no reliable and consistent evidence of appreciable recovery in absolute abundance" of this stock.

Reeves and Heide-Jørgensen (1996), who analyzed data from aerial surveys conducted between 1981 and 1994 off West Greenland, concluded that the historical wintering grounds were still visited by at least a few tens of whales and that the population was still a small fraction of its former size. This fraction is almost certainly less than $5 \%$.

\section{Hudson Bay Stock}

This stock was never large, probably limited by the lower carrying capacity of Hudson Bay. Yankee and Scottish whalers took at least 568 whales around Southampton Island, particularly from Roes Welcome Sound, between 1860 and 1915 (Ross, 1979, 1993). Reeves and Mitchell (1990:35) estimated that the population numbered at least 600 before this fishery, and concluded that it still numbered "at least a few tens," specifying that this was only a summary of available sightings "not sufficient for estimating population size." Woodby and Botkin (1993), using Ross's data, estimated a pre-exploitation population size of 575 and a residual population of 150 . However, these estimates are not reliable because they did not take into account the unexploited portion of the population that existed in Foxe Basin. Woodby and Botkin (1993) discussed the importance of the residual population size in estimating the current maximum population size and thus recovery rate. Such estimation is particularly problematic when considering records from the dying days of the industry, when profit motives and technology were in rapid transition. These qualifications are essential to arguments concerning the rate of recovery.

Surveys of the Hudson Bay stock were initiated in 1994 (Cosens et al., 1997). During reconnaissance surveys by aircraft and boat in June, they observed only two whales on the former Roes Welcome grounds, but 20-30 along the floe edge in northern Foxe Basin. In August, they found bowheads aggregated in the same general area. During two systematic surveys, they counted 47 and 53 whales over 362 and 414 linear km, respectively, which extrapolated to $256 \pm$ SE 31.3 and $284 \pm 48.6$. In 1995, Cosens and Innes (2000), focusing their survey efforts in northwestern 


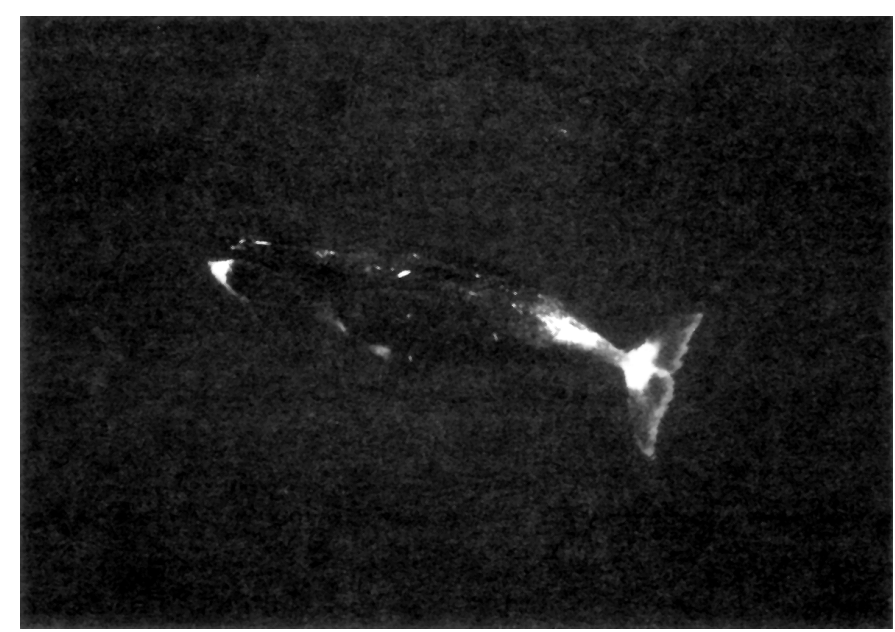

FIG. 2. Aerial photograph of adult bowhead, Isabella Bay, 28 August 1994. The amount of white on the tail and the degree of scarring indicate that the animal is old.

Hudson Bay in August, observed a total 15 whales, most aggregated near Repulse Bay. Too few whales were observed to determine their density using line-transect methods, so an extrapolation was made from seven observations determined by inclinometer. This resulted in an estimate of 75 , with a $95 \%$ confidence interval of $17-133$.

Estimates from 1994 and 1995 were combined to give 345 , believed to be a "minimum number known to be present rather than an estimate of actual stock size" (DFO, 1999b:3). Cosens and Innes (2000) concluded that this estimate is conservative because it did not account for submerged or missed whales. This level of certainty is unwarranted, given the methodological problems and the confidence interval of the estimates. In both years, the distribution of whales was too strongly clumped to allow reliable extrapolation. Another difficulty, in addition to the inherent methodological problems, is to determine the number of animals on the surface. Despite Reeves and Mitchell's (1990) explicit qualification, Cosen and Innes (2000:37) stated that "the results suggested the presence of significantly more than the few tens of bowhead whales previously assumed." Moreover, the DFO suggested that the stock had recovered to more than $50 \%$ of the estimated pre-exploitation stock size (DFO, 1999a).

\section{NATURAL HISTORY}

The only baleen whale adapted to Arctic seas, the bowhead is a filter feeder, highly dependent on Calanus copepods, the basis of the Arctic marine food web. The consequences of the bowhead's effective removal from the food web are unknown, but may be similar in magnitude to changes noted in Antarctic penguin and seal populations after reduction of the baleen whales. Quite likely some of the alcids, such as the murre (Uria lomvia) or the dovekie (Alle alle), and the ringed seal (Phoca hispida) benefited by the bowhead's decline. Lowry (1993) suggested that competition with arctic cod (Boreogadus saida) and Parathemisto amphipods could impede the bowhead's recovery.

Special adaptations of the bowhead include longevity, massive energy storage, a sophisticated acoustic sense for ice navigation and long-range communication, and an elevated 'blow-hole' or crown for pushing up through ice to breathe. It has been called the "quintessential K-strategist" (Nerini et al., 1984), jargon for a large, long-lived species with low fecundity (MacArthur and Wilson, 1967). $\mathrm{K}$-strategists exemplify the thermodynamic principles of energy accumulation and conservation through large size and long generation time (Johnson, 1994, 2000). A Kstrategist with a fragmented meta-population and confined within a narrow niche, the bowhead has all the attributes of an endangered species that can easily be affected by human technology and climate change.

\section{Growth and Longevity}

Length at birth is 4 to $4.5 \mathrm{~m}$ (Nerini et al., 1984). Using historical whaling data, Finley and Darling (1990) found a close correlation between baleen length, body size, and oil yield. Using isotopic analysis, Schell and Saupe (1993) found a close correlation in juvenile whales between baleen growth and age. Rapid growth in the first year of life is followed by a long period of slow growth, apparently limited by the juvenile's feeding abilities and diet (Schell and Saupe, 1993). From weaning to maturity, bowheads increase in length at a rate of about $25 \mathrm{~cm}$ per year, more slowly than other baleen whales (Koski et al., 1992). Females become sexually mature at $12.5-14 \mathrm{~m}$ in length; males are generally smaller and likely achieve sexual maturity at a smaller size (Koski et al., 1993). Schell and Saupe (1993) concluded that females took at least 17-20 years to reach maturity; George et al. (1999) suggested that maturity is reached somewhat later than age 20 years. The caudal peduncle, which begins turning white around sexual maturity, is a useful field mark for relative size categorization, though it is not a certain badge of maturity (Davis et al., 1983; Finley, 1990).

All theory, population parameters, and anecdotes indicate that bowheads live a long time, perhaps longer than any other mammal (Fig. 2). The best anecdotal evidence of extreme longevity is the finding of six traditional harpoon heads in five different whales taken in Alaska since 1981 (Philo et al., 1993; George et al., 1999). Most of these harpoons were probably used in the last century, before the whaling industry was at its height (George et al., 1999). Using aspartic acid racemization of the eye tissue, George et al. (1999) estimated the age of four individuals (all males) to be over 100 years; one was estimated to be over 200 years. They suggested that the harsh conditions of a cold environment and low prey densities have led to slow growth, delayed maturity, and extended longevity to ensure reproductive success. 


\section{Reproduction}

Sexual activity occurs throughout the year, but the principal breeding season is in late winter and early spring (Nerini et al., 1984), apparently peaking in March or April when song activity is highest (Würsig and Clark, 1993). Newborn calves have been observed between March and August, but most appear to be born in April and May; gestation is thus about 13-14 months (Nerini et al., 1984; Koski et al., 1993). Lactation lasts about a year (Nerini et al., 1984). Birth intervals may be highly variable (4-7 years), and calving may occur in cycles related to climatic oscillations (Rugh et al., 1992). The anestrus period may be correlated with the strength of Calanus copepod production, as it appears to be in northern right whales (Balaena glacialis; Kenney, 1997, 1998). The reproductive life span probably exceeds 60 years (IWC, 1992). Sex ratios are unknown but, like age distribution, they may be skewed because of strong selection pressure from commercial whalers.

The gross annual reproductive rate (GARR), the ratio of first-year calves to the total non-calf population, has been estimated at about 5\% in the Bering Sea population (Koski et al., 1993). In Baffin Bay and on the traditional 'nursery' grounds of the archipelago, Davis and Koski (1980) recorded only four cow-calf pairs in 123 sightings in 1976 and 1978. They cautioned that some of these were probably counted more than once. When known different sightings only were taken into account, they estimated (without taking segregation into account) that calves comprised only $2.5 \%$ of the population. Finley (1998) observed five different cow-calf pairs in 11 years at Isabella Bay. Reeves and Heide-Jørgensen (1996) did not observe any calves during surveys of the wintering grounds. Thus, the GARR of the Baffin stock could be less than half that of the Bering stock.

Cosens and Blouw (1999) conducted photogrammetric surveys of the Foxe Basin aggregation of bowheads in August of 1996, 1997, and 1998. Subadults (less than $13.5 \mathrm{~m}$ long) accounted for 72 of 82 animals photographed, and calves (less than $7.5 \mathrm{~m}$ long) accounted for 18 of the 72 subadults. It is unclear whether all of the animals photographed were different, since the locations of several individuals overlapped and young animals generally don't have distinguishing marks. Only 10 of the 82 animals were larger than $13.5 \mathrm{~m}$. Cosens and Blouw (1999) suggested that adult males and anestrous females occupied another part of the range, probably northwestern Hudson Bay. This pattern of segregation in late summer is similar to the situation in the Baffin Bay population, and though segregation is not strictly maintained, it is a general rule that makes estimation of GARR problematic. Nonetheless, this nursery aggregation is the most promising evidence that the Hudson Bay population is recovering; its viability may be due to the fact that commercial whalers did not exploit the 'nursery grounds.'

\section{Mortality}

Apart from reported landed catches, it is difficult to document sources of mortality. Evidently the mortality rate of adults is low (George et al., 1999), and, as with right whales (Kraus, 1990; Knowlton et al., 1994), the highest mortality probably occurs within the first few years of birth.

Mitchell and Reeves (1982) documented low-level but persistent hunting of bowheads by Inuit after the cessation of commercial whaling, and suggested that this, along with killer whale predation and habitat instability, was responsible for their lack of recovery. Much of the hunting initially took place from communities that had inherited equipment from the commercial whalers; later, as the equipment became obsolete, small firearms were used, resulting in delayed death and beached carcasses. They noted (1982:66) that a "striking aspect of these persistent whaling efforts is their geographical scope. Some hunting has occurred in virtually all parts of the Eastern Arctic where bowheads regularly come within range of a major settlement. However, it is clear that certain communities have maintained a more vigorous interest than others in killing bowhead whales." These communities, particularly those in northwest Hudson Bay and Foxe Basin, have continued to take whales illegally and legally. At least three have been killed since 1994: a $7 \mathrm{~m}$ female in September 1994, near Igloolik (Gregoire, 1994a, b); a 15 m male in August 1996, near Repulse Bay (Bremer, 1996; Vlessides, 1998); and a $13 \mathrm{~m}$ male in July 1998, near Pangnirtung, Cumberland Sound (Laghi, 1998; Associated Press, 1998). The number of documented cases probably underrepresents the level of hunting mortality.

Dead whales float for long periods and tend to wash up on shore, usually attracting polar bears (Ursus maritimus) and humans. It is unlikely that many sightings of carcasses go unreported (Philo et al., 1993). Three carcasses were reported from Baffin coastal waters in 1987 and 1988, but cause of death was unknown (Finley and Darling, 1990). Five carcasses, mostly of young whales, were reported from northern Hudson Bay and Foxe Basin in 1999; two appeared to have bite marks from killer whales (Cosens, 2000). Although cause of death has seldom been ascertained, it is often attributed to killer whales (DFO, 1999a:9). Killer whales often leave superficial scratches and bite marks on bowheads (Finley, 1990); however, the damage they cause in deadly attacks is unmistakable, and the remains may be few, if any.

Predation by killer whales is undoubtedly one of the limiting factors for the Baffin Bay population (Mitchell and Reeves, 1982; Reeves and Mitchell, 1988; Finley, 1990, 1998). Scarring rates and other anecdotal evidence indicate that the Baffin Bay stock is subject to higher levels of predation than the Bering Sea stock (Finley, 1990; George et al., 1994), although the apparently higher scarring rate could also indicate the preponderance of older animals. Although they are not especially abundant in the Eastern Arctic, killer whales appear with regularity 
at certain places (Reeves and Mitchell, 1988; Campbell et al., 1988). These places were well known to the elders, and there are several eyewitness accounts of calves and juvenile whales being taken by killer whales (Finley et al., 1984; Finley, 1990). In September 1994, a juvenile was taken by killer whales near Broughton Island (M. Taylor, Department of Renewable Resources, Iqaluit, pers. comm., 1994). It appears that maximum predation pressure is exerted on calves and juveniles during autumn migration (Finley, 1990). Old animals as well as juveniles are probably more susceptible to killer whales, and it is possible that more of the population is succumbing to such predation because of advanced age (Finley, 1990, 1998). Predation is particularly critical for severely depressed stocks, because killer whales have abundant alternate prey and are not limited by a simple predator-prey feedback cycle. The shooting of 14 killer whales in Cumberland Sound in 1977 may have reduced some of the predatory pressure (Reeves and Mitchell, 1988). It is uncertain whether Hudson Bay whales are subjected to the same level of predation as the Baffin Bay population; there are relatively few sightings of killer whales on their summer range (Reeves and Mitchell, 1988).

Ice entrapment is also a potential source of mortality. Although bowheads are adapted to survive ice entrapment (e.g., as recently as 1996-97, a juvenile successfully overwintered in a small polynya in Admiralty Inlet, northern Baffin Island; G. Williams, Arctic Bay, pers. comm. 1997), fatal entrapments have occasionally occurred on their wintering grounds (Eschricht and Reinhardt, 1866).

\section{BEHAVIOUR}

\section{Locomotion}

Bowheads are slow, averaging only $2-5 \mathrm{~km} / \mathrm{h}$ during casual movements (Würsig and Clark, 1993; Richardson et al., 1995a). Mate et al. (2000) radio-tracked one whale that travelled at least $3886 \mathrm{~km}$ in 32.5 days, averaging $5.0 \mathrm{~km} / \mathrm{h}$ during autumn migration. When fleeing disturbance, bowheads can achieve $10 \mathrm{~km} / \mathrm{h}$ over short intervals, but they slow down quickly, perhaps because they are physiologically constrained by heat buildup (Finley, unpubl. data).

\section{Feeding}

Feeding behaviour of bowheads tends to be synchronous, within size cohorts, over large areas and long periods. In Baffin Bay, sounding dives of adult whales in troughs deeper than $200 \mathrm{~m}$ were stereotypic, averaging $22.3 \mathrm{~min}$ (max. $41 \mathrm{~min}$.) and occurring over several days when oceanographic conditions were favourable (Finley et al., 1993, 1998). In the Mackenzie Canyon of the Beaufort Sea, subadult whales regularly dove to depths between 100 and $200 \mathrm{~m}$ (max. $352 \mathrm{~m}$ ), for periods between
19 and 32 min (Krutzikowsky and Mate, 2000). Feeding behaviour changes with growth of the baleen and diving abilities. Adults tend to feed on Calanus copepods in offshore areas, whereas juveniles tend to feed on larger, swarming zooplankton, such as mysids or Euphausiids, or minute prey such as Pseudocalanus and Limnocalanus copepods in nearshore habitats (Gray, 1932; Bradstreet et al., 1987; Griffiths et al., 1987; Lowry, 1993). Whereas northern right whales specialize in feeding on the mature stages of C. finmarchicus (Mayo and Marx, 1994; Goodyear, 1996), Greenland whales apparently specialize in feeding on the mature stages of $C$. hyperboreus and $C$. glacialis.

Winter is evidently a period of fasting for bowheads because the bulk of the Calanus-dominated zooplankton community has retreated to great depths (e.g., more than $1000 \mathrm{~m}$ ). During spring and early summer, zooplankton is generally too dispersed and too lean to provide economical feeding conditions. But some feeding, especially by juveniles, does occur along ice edges and in pack ice (George et al., 1989; Brett, 1999). It appears that the bulk of the adults' energy requirements are met during a short period in autumn, when mature stages of Calanus copepods are concentrated in density and energy content by atmospheric and oceanographic processes (Finley et al., 1993). The level of bowhead feeding activity is a good indicator of energy flow through the marine ecosystem (Finley et al., 1993, 1998).

\section{Social}

Bowheads are social animals, both in terms of being gregarious and in terms of their close interactions with each other. Würsig et al. (1985) found that whales scattered over large areas of the Beaufort Sea often had synchronous behaviour, such as feeding or socializing. This behavioural synchrony has also been noted at Isabella Bay, particularly within size cohorts; when conditions are favourable, the herd generally feeds, and when conditions are unfavourable, the whales tend to aggregate and socialize at or near the surface. Close social interactions include pushing, caressing, and chasing; adolescents often engage in high-energy sexual activities, including long bouts of tail slapping, breaching, and screaming (Würsig and Clark, 1993; Richardson et al., 1995a).

\section{Breeding}

Breeding takes place in early spring, apparently peaking in March or April when song activity is highest. Although balaenid whales are generally polygynous, there is no solid evidence as to the bowheads' mating strategy (Würsig and Clark, 1993). Brownell and Ralls (1986) suggest that their massive testicles (maximum $105 \mathrm{~kg}, \mathrm{C}$. George, North Slope Borough, pers. comm. 1998) support the theory of sperm competition, as does the occurrence of large, sexually active groups (Everitt and Krogman, 1979). 
However, most observations have been made outside the breeding season, and most involve adolescents (Würsig et al., 1985; Finley, 1990).

\section{Communication}

Bowheads are the most vocal of the large whales, and their repertoire is one of the most complex of any baleen whale (Clark, 1991). Intense calls (up to $170-180 \mathrm{~dB}$ in the $100-1000 \mathrm{~Hz}$ band) are used for communication and navigation (Cummings and Holliday, 1987; Würsig and Clark, 1993). Most calls during spring migration are lowfrequency sweeps or ' $J$ whoops,' evidently used for longrange communication and herd navigation (Clark and Johnson, 1984; Clark, 1991). These contact calls are seldom heard in autumn at Isabella Bay; instead, a variety of broadband pulsed calls are used (Richardson et al., 1995a). Bowheads sing complex, highly variable songs during the breeding season (Würsig and Clark, 1993).

\section{Killer Whale Phobia}

Bowhead behaviour is strongly influenced by fear of killer whales. This fear, known as 'ardlungaijuq' or 'aarlungajut' in the Inuit language, causes marine mammals to seek cover in ice and, if that is unavailable, in shallow waters (Finley and Miller, 1982). Ardlungaijuq behaviour is recognized by experienced Inuit hunters as being sometimes very subtle or not so subtle. Threatening noises, such as ships, boats, gunfire, and seismic explosions, can also evoke the reaction. The whales respond in various ways, depending on their age, their level of exposure to killer whales and industrial activity, and the proximity of protective cover. Gray (1926) believed that male bowheads "because they have least to fear from natural enemies, are found in the most exposed and open situations" and that the females and juveniles "keep to deeper situations amongst the ice, and disappear early in the season into its recesses." Juveniles typically show an inconspicuous, coast-hugging behaviour, and the autumn migration route closely follows the shore. In the absence of ice, adults abandon offshore areas, coalesce in shallows, and show defensive behaviour such as tail slapping. This predator avoidance response has been used effectively by Inuit hunters (Mitchell and Reeves, 1982). Today, the close association of cow-calf pairs and juveniles along the floe edges of northern Baffin Island, together with ardlungaijuq responses to ship traffic (e.g., Finley et al., 1990), may make the bowheads more vulnerable to hunting.

\section{ESSENTIAL HABITATS}

Habitat requirements are set by threshold levels of zooplankton density and energy, which are ultimately determined by climate, oceanographic processes, and copepod ecology. Habitat partitioning occurs according to diving abilities. Juveniles tend to skim-feed along floe edges in spring and use coastal eddies in summer. Important feeding habitat for adults in Baffin Bay has been defined as a permanent, localized feature created by large-scale biophysical processes (Finley et al., 1993, unpubl. data).

Payne (1995) suggested that the shelter of pack ice fields is the main reason bowheads are able to winter in stormy high latitudes. Ice also provides protection from killer whales and a 'superstrate' or ceiling for algae production and zooplankton concentration in spring. During late summer and autumn, when they may be without ice shelter, bowheads are more vulnerable to killer whales. At Isabella Bay, a shallow bank offers protection from these predators (presumably because it restricts attacks to two dimensions) and provides a place to rest and socialize close to essential feeding habitat (Finley, 1990).

Calf-rearing areas, or 'nursery grounds,' were well known to the whalers as those inaccessible recesses of the archipelago, particularly Prince Regent Inlet and Admiralty Inlet, where persistent ice provided protection from the whalers (until the advent of steam-powered vessels in 1860) and from killer whales (Brown, 1868; Gray, 1926, 1927). The recently documented nursery ground in northern Foxe Basin (Cosens and Blouw, 1999) was not discovered by the whalers and still remains largely out of bounds for killer whales.

Migration corridors are often narrowly confined in space by ice and coastal topography. Important corridors include the spring migration route through Lancaster Sound and the autumn route along the northeast coast of Baffin Island.

\section{ENVIRONMENTAL THREATS}

\section{Climate Change}

Climatic change has a major impact on Arctic marine ecosystems in general (Vibe, 1967; Tynan and DeMaster, 1997) and on the productivity of bowhead feeding habitat in particular. At Isabella Bay, the level of feeding activity is highly variable, with notable reductions in El NiñoSouthern Oscillation (ENSO) years (Finley et al., 1993). Because there is a significant negative correlation between the ENSO and sea-ice conditions in the Baffin Bay-Labrador Sea region (Wang et al., 1994), and because of its situation beneath a major atmospheric trough (Jacobs et al., 1974; Maxwell, 1982), the Baffin Bay ecosystem is particularly sensitive to global climatic perturbations, as shown by its effects on the Thule and Viking cultures (McGovern, 1980). Because bowhead fecundity is probably related to the strength of Calanus production, global warming and climatic perturbations are likely to have an impact on population growth, either negative or positive, through changes in the extent of sea ice. In contrast to other Arctic regions, Baffin Bay has experienced heavier than normal ice seasons in recent decades (Parkinson, 2000), with reduced Calanus production and whale feeding in 
years of major climatic oscillations (e.g., in 1983, 1987, and 1992; Finley et al., 1983, unpubl. data). Climate change could also affect the population more directly through increased risk of ice entrapment on the winter grounds, or decreased ice cover on the summer nursery grounds, resulting in increased predation. Though bowheads have adapted to climatic oscillations of the past, present accelerated changes will likely affect relict stocks more profoundly.

\section{Entanglement and Accidental Ingestion}

Kapel (1985) reported the drowning of a juvenile bowhead in a marine mammal net in Northwest Greenland. Plastic debris, which poses a potential danger from bowel obstruction (Philo et al., 1993), has been found in the stomachs of western bowheads. Such debris is often found drifting through bowhead feeding areas in western Baffin Bay and could pose a risk, particularly for skim-feeding subadult whales.

\section{Toxins and Pathogens}

Bowheads are not as prone to concentrate contaminants as toothed whales are; however, over their long life span, they can accumulate toxins. Cadmium concentrates in their liver and kidneys, but tissues of Bering Sea whales are low in most natural and man-made contaminants (O'Hara et al., 1999). From whales in this same population, antibodies have been isolated for a marine calicivirus that could cause death or health problems (O'Hara et al., 1998).

\section{Noise Pollution}

Because they use long-range communication and are attuned to low-frequency noise of sea states and ice, bowheads are sensitive to low-frequency industrial sounds. They show a wide range of responses to various vessels and industrial noises, such as drilling platforms (Richardson and Malme, 1993). Although the behavioural repertoires of eastern and western whales are similar, there are qualitative and quantitative differences that are probably due in part to differences in exposure to industry and hunting activities (much less in the east, Richardson et al., 1985, 1987, 1995a) and to predation pressure (apparently more in the east). The behavioural differences may also be genetic. For example, the noted shyness and wariness (a heritable trait in some species) of Baffin Bay whales may be a legacy of the whaling era; i.e., if only the most wary whales survived, the fragmented populations of the present day would be derived from a limited, isolated, wary, founder population.

At Isabella Bay, bowheads respond at long ranges to ships by moving into shallow waters. In the Beaufort Sea, Richardson et al. (1995b; W.J. Richardson, pers. comm. 2000) found that migrating bowheads stayed at least $20 \mathrm{~km}$ away from seismic vessels, drilling ships, and support vessels. Wartzok et al. (1989) observed that skim-feeding whales were sometimes oblivious to a research vessel and, in fact, accidentally bumped into it while the motor was still idling. At Isabella Bay, the whales usually react strongly to outboard-powered boats and attempt to flee at long ranges (i.e., beyond the passengers' vision), but they soon slow down. When overtaken, they often appear unwary, leading to a mistaken belief that outboard-powered boats do not disturb them. The 'inconspicuous' behaviour of western whales during autumn migration may be attributable to whaling or industrial activities, or both (Richardson et al., 1987, 1995a).

\section{Tourism}

In a world review of the reactions of cetaceans to whalewatching activities, Findlay (1997) rated bowheads as the shyest of all large whales. Tourism and whale-watching are being strongly promoted in Nunavut. Clyde River and Isabella Bay are particularly noted for bowheads, and the community has plans for a sanctuary. Although travel to Isabella Bay has been curtailed by its remoteness and adverse weather, the acquistion of larger, faster boats (Finley, 1990) and publicity on the whales (Nicklin, 1991, 1995; Reed et al., 1998) are changing this. In 1995, an icestrengthened Soviet ship, the Alla Tarrasova, took a whalewatching cruise to Isabella Bay. Such activities have a great potential to disturb and displace the whales.

\section{TRADITIONAL KNOWLEDGE}

In part because of disciplinary specialization, science has an unfortunate history of ignoring local rural knowledge. It also has a history of not being able to 'see the forest for the trees' because its observations are usually of short duration and lack observer continuity. This epistemological difference has given legitimacy to a new 'discipline,' often called Traditional Ecological Knowledge, or TEK (Ferguson et al., 1998; Huntington, 1999). According to Edwards (1998:18), Canada is recognized as a leader in the implementation of TEK, particularly as it relates to the rationalization of a hunt for the bowhead: "The Canadian government's decision to relax a ban on the hunting of the bowhead marked a watershed in scientific attitudes to indigenous knowledge. For the first time, scientists took heed of what the Inuit knew about the animals... As a result, scientists have revised their estimates." TEK gained legitimacy in the earlier controversies over the Alaskan bowhead hunt by showing that initial scientific estimates of the population size, which conflicted with hunters' beliefs, were too conservative (Mitchell and Reeves, 1980). This led to a backlash against science and the IWC (e.g., Freeman, 1990; Finley, 1991) which in turn, has led to skepticism: e.g., "Accepting TEK without question denies it the status of worthwhile data; critical evaluation and careful use give TEK the status it deserves" (Huntington, 1999:59). 
The general belief expressed in the Nunavut bowhead knowledge study (NWMB, 2000) - that whale populations have increased in recent decades-constitutes a scientific hypothesis. Opinions from scientific experts cannot be accepted as proof that something is true, any more than local opinions can. In both cases, opinions can be used to develop a hypothesis, but they must withstand scrutiny for potential biases considering political context, vested interests, and the pitfalls of leading questions and circular reasoning. For example, Anderson (1934:72) reported that the "natives [of Cumberland Sound] said that 'whale food' had been scarce for several years and the whale is coming back because "whale food' is more abundant." This report was written during a period when the Hudson's Bay Company was encouraging the commercial exploitation of small whales in Cumberland Sound; thus, there may have been some incentive for hunters to exploit the larger prey. Again, during the first economic surveys of Baffin Island, hunters stated that sightings had increased in the last decade, and noted the whales' regular appearance around Clyde River in late summer (Anders et al., 1967). During that period, Clyde River people were attracted to the American military base (now gone) at Cape Christian, where they were much more likely to see bowheads. Today, there is a widespread and understandable belief that bowheads must be increasing because they have not been hunted (NWMB, 2000).

Permission to hunt bowheads in Nunavut was made contingent on the results of the bowhead traditional knowledge survey (DIAND, 1993:38). In general, Inuit believe that the number of bowheads has increased significantly since the 1960s, particularly around Clyde River, Igloolik, and Pangnirtung (NWMB, 2000). Not all interviewees supported this view, and many were uncertain whether there had been any change in numbers. Also, hunters in Greenland do not generally believe that the population is increasing (Reeves and Heide-Jørgensen, 1996). Similarly, when I conversed with elders from northern Baffin Island in the late 1970s, they did not generally indicate that the population had become more numerous (Finley et al., 1983). Some of these elders participated in the Cape Adair and Isabella Bay studies, and many are now deceased. However, their knowledge was passed on to many in the community. In time, "it was hard to tell where any boundary existed between formal scientific knowledge and local or traditional knowledge- they were so well blended and adopted into the awareness of both the community and the scientist" (Myers, 1990). This integration of knowledge is evident in the NWMB study, with its many references to Isabella Bay. As Usher (2000) points out, contemporary TEK explanations can hardly be unaffected by aboriginal people's knowledge of the wider world, particularly since aboriginal Northerners have been employed in field science programs since the 1960 s.

Several related socioeconomic factors could account for the perceived increase in bowheads over the past few decades. These include 1) a major movement into settlements in the early 1960s, 2) the generation gap and experiential discontinuity, 3 ) the re-establishment of outpost camps in the late 1970s and early 1980s, 4) the acquisition of larger, faster boats, and 5) the proliferation of portable radios. Traditionally, during late summer and autumn, Inuit moved inland to hunt caribou and fish for char, and their range did not generally overlap with that of the bowhead; in fact, they avoided the outer coast because of poor weather and high seas. This pattern has changed dramatically in the last few decades. Hunters are now much more likely in autumn to travel the outer coast, where they will more likely encounter bowheads. For example, the majority of sightings reported during the Isabella Bay studies were made by hunters travelling northward along the outer Baffin coast to caribou hunting grounds (Finley, 1990, 1998). Larger, faster boats and radio communication have made such long-distance travel possible. Thus the perceived increase in numbers of bowheads could be explained by increased opportunities to see them and the ability to report these sightings. Indeed, given the low rate of increase in bowhead numbers, it would be difficult to detect a trend over a few decades that was independent of the increase in sighting opportunities.

In addition to the factors just noted, media publicity strongly influenced public perception during the period leading up to the bowhead traditional knowledge study. The Isabella Bay studies received publicity locally, on the Inuktitut radio network, and regionally, through film, $\mathrm{CBC}$ radio, and print. On the few days when whales were spectacularly abundant, almost everyone listening to the radio network over northern Baffin Island and Foxe Basin was well aware of it. Also, with the strong push to develop tourism, the community of Clyde River made the most of its reputation as a place to see lots of bowheads. This reputation is evident in the bowhead knowledge study (NWMB, 2000:22): "Clyde River and nearby Igaliqtuuq/ Isabella Bay are well known for hosting large numbers of bowheads." Finally, in 1995, the spectacular stories concerning the drowning of four American tourists, attributed to an encounter with a bowhead whale (Philips, 1995), sealed the popular belief that bowheads were increasing and needed culling. Freeman (1996) suggested that the whales had "become a hazard to hunters," and that "the tragic drowning of four tourists, whose boat was capsized by a surfacing whale in northern Baffin Island last summer, certainly suggests that local hunters are not being alarmist in stating they now avoid certain areas where they are numerous." Unfortunately, Freeman used this anomalous incident to challenge the 'conventional wisdom' of southern scientists. It is understandable that hunters, especially older hunters, would avoid boating among bowheads simply because of their impressive size and whaling stories about their violent death throes, though this fear was diminishing as the hunters became familiar with the bowheads at Isabella Bay.

Local knowledge is invaluable in piecing together the natural history of a region and a species-without it, the 
Isabella Bay studies would not have been initiated. Although this knowledge should be taken into account, it cannot take the place of the scientific method and the best data available in evaluating a species status and in prescribing a management plan.

\section{REGULATIONS AND REGULATORY AGENCIES}

\section{International Convention for the Regulation of Whaling}

The plight of the right whales (Balaenidae) galvanized international action in 1931 at the League of Nations Convention in Geneva. The Convention, which came into force in 1935, prohibited the killing of all right whales except by aboriginal subsistence hunting using traditional technology. This exemption was deleted from the 1937 Whaling Agreement, but the prohibition was never enforced, and bowheads continued to be hunted in Alaska, Canada, and Russia (Mitchell and Reeves, 1982; Gambell, 1993). After the Second World War, the International Convention for the Regulation of Whaling established the International Whaling Commission to oversee the regulation of commercial whaling. Aboriginal whaling was exempted from the general regulations of the IWC, provided that the hunters used traditional whaling crafts and weapons, and that the products were used only for local consumption (Gambell, 1993). In 1980, in response to the Alaskan bowhead hunt, the IWC began to develop management principles and guidelines for aboriginal subsistence whaling (Gambell, 1993).

Canada ratified the Whaling Convention Act in 1951, banned commercial whaling in 1973 (Mitchell and Reeves, 1982), and supported the IWC recommendation for full protection of the bowhead in 1977 (Anonymous, 1977). Amendments to Canadian regulations in 1979 prohibited hunting by aboriginal people except by special license (DFO, 1979). But Canada withdrew from the IWC and repealed the Whaling Convention Act in 1982, the same year in which the IWC recommended complete protection from all forms of hunting for North Atlantic stocks of bowheads (IWC, 1982).

In 1991, Canada issued a permit to the Inuvialuit to take a whale from the Bering Sea stock, from which many whales enter Canadian waters. The IWC protested, urging Canada to rejoin and seek international approval. Canada did not comply and instead developed a 'co-management' agreement, which stated that the permit would be applied within the IWC quota of 51 then allotted to the Alaskan Eskimo Whaling Commission. In response to the 1996 hunt in Hudson Bay, the IWC passed a resolution requesting that Canada refrain from issuing further permits without obtaining IWC approval for its whaling activities (IWC, 1996). The IWC has continued its strong protest against Canada's actions, passing resolutions in 1998, 1999, and 2000. At the last meeting, the IWC noted that Canada is signatory to the United Nations Convention on the Law of the Sea, which (under Article 65, Marine Mammals) requires states to cooperate through the appropriate international organizations for the conservation, management, and study of cetaceans (IWC, 2000a). It again invited Canada to rejoin and, in the meantime, not to issue further whaling permits without IWC approval.

Canada shares the Baffin Bay stock with Greenland, where the bowhead is fully protected (Reeves and HeideJørgensen, 1996). Denmark regulates Greenland's whaling activities through its membership in the IWC, and it has abstained from supporting the IWC resolutions concerning the Canadian hunt.

In addition to setting quotas, the IWC recommends use of whaling technologies appropriate for reducing pain, wounding, and loss rates (Mitchell et al., 1986; Øen, 1995). The 1996 killing of a large bowhead with rifles in Nunavut (Vlessides, 1998) did not meet any standards of humane killing. Although the DFO states that, within Nunavut, "traditional hunting practices are encouraged, as is the hunting of animals that were traditionally used" (DFO, 1999b:3), traditional techniques are not appropriate by themselves and can result in prolonged agony and high loss rates. Hunting practices through the last century were adapted from the commercial whalers, using their technology, and when harpoon guns became obsolete, rifles were used. Traditionally, Thule Eskimos selected small whales (less than $9 \mathrm{~m}$ ) almost exclusively because the killing of large whales was impractical (Durham, 1974; Savelle and McCartney, 1990).

\section{The Nunavut Land Claims Agreement}

The Nunavut Wildlife Management Board (NWMB), created by the land claims agreement (DIAND, 1993), consists of nine members appointed by designated Inuit organizations and representatives of the DFO, Canadian Wildlife Service, and the Department of Indian Affairs and Northern Development (DIAND). Although the agreement recognizes that the federal government has ultimate responsibility for wildlife management, the NWMB is recognized as the main instrument responsible for the establishment of conservation areas, approving plans for wildlife protection, and approving designation of endangered species. Section 5.5 states that the government acknowledges the Inuit view that, following the cessation of commercial harvesting, stocks of bowhead whales in the Nunavut Settlement Area have increased in recent decades, in part as a result of the Inuit's voluntary curtailment of their harvesting practices. The agreement provided the NWMB $\$ 500000$ to conduct an Inuit knowledge study to record sightings, locations, and concentrations of bowhead whales in Nunavut. Section 5.6 states that by the first anniversary of the commencement of the study, the NWMB shall establish a total allowable harvest of at least one bowhead whale, subject to conservation requirements and considering the results of the study to date and other information as may be available to it. 


\section{The Fisheries Act and the Oceans Act}

The Fisheries Act assigns the Minister of the DFO ultimate responsibility for the conservation of the bowhead, and the Oceans Act requires the Minister to use the precautionary principle in its management.

In response to the Nunavut agreement, the DFO's Arctic Fisheries Scientific Advisory Committee (AFSAC), advised by the National Marine Mammal Peer Review Committee (NMMPRC), was asked to provide sustainable yield estimates "consistent with the land claim definition of conservation" (S. Innes, DFO, pers. comm. 1998). NMMPRC's report to AFSAC stated that "no data are present for the bowhead whale stocks in eastern Canada," and that "it can be inferred from historic and recent estimates of population size, and from traditional knowledge studies, that these stocks have increased in size since the 1920s." It recommended that "there should be no increase from the [present] rates of removal.... [which] are approximately one whale per three years for the Foxe Basin/Northern Hudson Bay stock and one whale per 13 years for the Baffin Bay/Davis Strait stock" (DFO, 1996b:24). Neither the NMMPRC nor the AFS AC report contained any reference to field studies and scientific publications on the Baffin population.

NMMPRC's assessment depended on population viability analysis by Innes (1996), using the 'VORTEX' model (Lacy and Kreeger, 1992) and parameters and assumptions from the Bering Sea stock of bowheads. Though its weakness was acknowledged, the model predicted that the "removal of one adult female from the modeled population did not change the probability of extinction or population size after 100 years" (DFO, 1996a:9). Foley (1997:217) cautioned that programs "such as...VORTEX are good at including age structure and other biological details, but they need extensive runs to cover much parameter space. They can be made to do the job of comparing [conservation] strategies, but at some cost in time, generality, and conceptual clarity."

AFSAC was replaced by the Regional Advisory Process (RAP) in 1997, and a RAP meeting was held in Iqaluit in June 1999 to examine the status and set a sustainable hunting rate for the Hudson Bay bowheads (DFO, 1999a). The participants chose Wade's (1998) Potential Biological Removal (PBR) approach to estimate a sustainable hunting rate. This method was deemed to be precautionary (DFO, 1999a) even though the assumptions and parameters used were not: for example, the recruitment rate was set as the "expected maximum" of $4 \%$ per year for cetaceans in general (DFO, 1999a:4). The RAP recommended a safe harvest level of one whale every two years. Wade, an external reviewer, commented that the PBR approach was developed for the U.S. Marine Mammal Protection Act, which provided a theoretical and legal framework for ensuring that populations are maintained at optimal levels; it was not designed for managing the direct exploitation of small populations (DFO, 1999a).
Committee on the Status of Endangered Wildlife in Canada (COSEWIC)

COSEWIC has listed bowheads as "endangered" since 1980 (Mansfield, 1985; Reeves and Mitchell, 1990), although it has recommended down-listing the Bering Sea stock to "vulnerable" status (Houston and Campbell, 1996). The proposed Species at Risk Act, introduced into the House of Commons on 10 April 2000, would have made it illegal to kill, harm, harass, or take a listed, extirpated, endangered, or threatened species (McIlroy, 2000a). Listing of species would have been decided by parliamentary discretion, on the basis of advice from COSEWIC. The Act would not have required that scientific designations be adopted, nor would it require any form of justification for listing decisions that diverged from those of COSEWIC (McIlroy, 1999a, b, c; Scudder, 2000). With the federal election in October 2000, the proposed act died on the table.

\section{Igaliqtuuq National Wildlife Area and Biosphere Reserve}

Since 1987, the community of Clyde River, with the support of the WWF, DIAND, and Environment Canada, has worked toward the protection of bowhead whale habitat at Isabella Bay (WWF, 1987). After looking at many options, the community proposed the creation of Igaliqtuuq National Wildlife Area (NWA) and UNESCO Biosphere Reserve (Anonymous, 1990; Myers, 1990; UNESCO, 1994). The sanctuary was to have encompassed special habitats and limited activities that might disturb the whales. Although agreement in principle was reached, there was external concern that the sanctuary agreement did not exclude oil exploration or cruise-ship activities, or have enough authority to protect whales from harassment by tourists. Some parties with vested interests opposed this requirement. This and other problems posed impossible compromises on the integrity of the proposed sanctuary. Finally, after several years of working through the Nunavut implementation process, negotiators broke off talks in 1999 over compensation issues (Weber, 1999). World Wildlife Fund continues to work with the community and places high priority on the creation of a sanctuary (WWF, 2000).

\section{MANAGEMENT POLITICS}

The history and status of Greenland whales have many similarities with those of the North Atlantic right whale, an endangered species that numbers around 300 (IWC, 2000b). Despite enormous research efforts, vital parameters of right whales remain uncertain; it is agreed that their rate of increase is very low and highly variable, and that calving intervals, evidently correlated with climatic oscillations (Kenney, 1998), have increased significantly in recent decades (IWC, 2000b; Kraus et al., in press). Given present trends, the population appears doomed to extinction 
(Caswell et al., 1999). The IWC has stated that it is a matter of absolute urgency to reduce human-induced mortality (ship strikes and net entanglement) to this population (IWC, 2000b). It is reasonable to assume that the biological potential of Greenland whales is similar to that of right whales, if not even more limited, and that the margins for error in management are less forgiving. Indeed, many of the past assumptions about their life history parameters have fallen short of recognizing their true biological potential. Schell's groundbreaking research (Schell et al., 1989) brought about a change in understanding of the limited growth and reproductive potential of the species and suggested the need for a more conservative approach to its management (Pain, 1987). The recent discoveries regarding longevity by George et al. (1999) support this conclusion. Burns (1993) cautioned that our understanding of the species was based mostly on short-term studies of remnant populations, and that these provided little insight about longer-term dynamic ecological relationships and changes in population characteristics. As is well demonstrated in the case of the right whale, there will never be sufficient funds to quantify the life parameters necessary to manage the species so finely; to play statistical brinkmanship with such odds is irresponsible, and the consequences won't be known for a long time. Greenland whales have all the earmarks of an endangered species that requires prudent application of the precautionary principle, a requirement of the Oceans Act (DFO, 1998).

Using the humpback whale as an example, Gerber and DeMaster (1999) developed a quantitative approach to endangered species classification of long-lived vertebrates. Their criteria included the uncertainty principle that classification criteria should be more conservative where data are limited or unavailable, and required that an international regime be in place and be effective in regulating human-related disturbance and mortality. They stated that levels of risk associated with different assumptions about population structure should be made explicit. They set the threshold for endangered status at 500 individuals, but noted that such an estimate was highly dependent on population parameters such as age structure and sex ratio, and that even with perfect information, it may not be possible to estimate such a number with any confidence. In the absence of knowledge of population structure and birth and mortality rates, the most conservative assumptions should apply. Clearly, by these criteria and the example of the right whale, the precautionary principle can only mean complete protection for the Greenland whale until it reaches an optimal level that allows a sustainable take.

Although the Greenland whale has long been recognized by COSEWIC as an endangered species, it has no legal protection as such and there are no clearly stated management goals for its recovery. By contrast, the United States has a strong Endangered Species Act in addition to the Marine Mammal Protection Act. The proposed Canadian Species at Risk Act (SARA) was strongly criticized for allowing too much political discretion in the listing of species (McIlroy, 1999b, 2000b; Scudder 2000), and the independence and scientific integrity of COSEWIC have been questioned (McIlroy, 1999c). Minister of the Environment David Anderson stated that any new law required flexibility, and that the way to get flexibility was to build in cabinet discretion. "People are not going to accept some decision by a biologist who they have never seen and who has never talked to them. People expect to have their say before a decision is taken," he said (Winsor, 2000:A4). Obviously, the case of the Greenland whale will test the efficacy of SARA and COSEWIC.

Kellert (1985:528) advised that "an effective strategy for protecting endangered species will require an increasing recognition that most contemporary extinction problems are the result of socioeconomic and political forces." He noted that the typical biological and technological emphasis for solutions reflected an expedient response to the political pressures of a government and public that demand immediate remedial action rather than fundamental and long-term social and perceptual solutions.

When I initiated studies of the bowhead at Isabella Bay in 1983, it was with some optimism, tempered by experience with Inuit hunting of small whales (e.g., Finley and Miller, 1982). The success of the first year of studies was due considerably to the elders' knowledge (Finley et al., 1983; Finley, 1990). In a progress report to World Wildlife Fund, I concluded that

meaningful participation in research is essential if the Inuit are to develop an understanding of research methodologies and their application in developing management strategies. Participation is necessary to bridge the cultural gap between local knowledge and applied science, and to provide a mutually credible basis for the development of regulatory policy. Conservation education would be useful in illustrating the relationship between regulatory policy and local self-interest, and in developing a broader understanding of the geographical scope of conservation policy. (LGL Ltd., 1986:4)

At the conclusion of the WWF program in 1985, the steering committee, including scientists and administrators from the DFO, commented on the outstanding cooperation and involvement of the local people and recommended that the program continue with long-term monitoring (Hummel, 1986). The studies were extended for two years, and in 1987, with the expectation that the DFO would continue the work, a department biologist was invited to participate. Although a progress report was prepared, outlining the many opportunities for future studies, nothing came of it. Again, in 1992, the DFO was invited to participate in an interdisciplinary project at Isabella Bay (Finley et al., 1993; Innova, 1994) but declined, stating that the project was not a research priority. This lack of priority was reflected in the expenditures for bowhead research by various American and Canadian agencies up to 1992: DFO accounted for only US\$237 000 
out of a total $\$ 56.4$ million (Montague, 1993). It was also reflected by the absence of any DFO contribution to the monograph of the species (Burns et al., 1993). A year later, after the right to take bowheads was entrenched in the Nunavut Land Claim Agreement (DIAND, 1993), the department was finally galvanized into action.

The department's long inaction is incomprehensible, considering that its own scientists had warned of impending problems. Mitchell and Reeves (1982:66) stated:

[It] is evident that protection from hunting in the Eastern Arctic since 1915 has not been as complete as is often assumed...On the contrary, some shore-based hunting, usually by Inuit but sometimes with the involvement of local white residents, has continued without interruption in Canada, and to a lesser extent Greenland...A striking aspect of these persistent whaling efforts is their geographical scope. Some hunting has occurred in virtually all parts of the Eastern Arctic where bowheads regularly come within range of a major settlement. However, it is clear that certain communities have maintained a more vigorous interest than others in killing bowhead whales.

These communities, particularly Repulse Bay and Pangnirtung, the last outposts of Euro-American commercial whaling, conducted the most recent hunts (Vlessides, 1998; Associated Press, 1998) and exerted much of the pressure to resume whaling.

Although the federal government is ultimately responsible for endangered species, the Nunavut Wildlife Management Board is effectively responsible, approving plans for research, management, and protection. Article 5.2.37 of the Nunavut Agreement states that the ability and right of the federal government to continue its own research functions shall not be prejudiced; accordingly, the NWMB shall review research proposals and recommend acceptance or rejection. The NWMB has veto power. For example, one of the more cost-effective ways to monitor the Baffin population would be to repeat the migration study at Cape Adair (cf. Davis and Koski, 1980), but apparently the NWMB rejected a DFO proposal to conduct such research. This, and the following audit, indicate that the DFO's research functions have been prejudiced. For example: "It can be inferred from historic and recent estimates of population size, and from traditional knowledge studies, that these stocks have increased in size" (DFO, 1996b:24). "Community participants wanted to be sure that their disapproval of the 'endangered' status and their view that the stock should be delisted would be clearly noted" (DFO, 1999a:7). The subsequent Stock Status Report states that "Current information suggests that the endangered status may no longer be applicable" (DFO, 1999b:5). To maintain cooperation and conduct research, it would appear that the DFO is obliged to support the belief that bowhead stocks have increased and are not endangered.

Hutchings et al. (1997) point out many problems with the DFO in regard to fisheries management that also apply to the bowhead. They include bias in stock assessment reports, selective exclusion of scientific information, suppression of scientific uncertainty, and lack of independent peer review. They observed that bureaucratic action had a stifling effect on scientific debate within the department and that external expertise was often ignored or denounced. This stifling effect is more pronounced within the small arena of Arctic fisheries and the limited coterie of marine mammal biologists. Although the bulk of scientific expertise on the bowhead exists outside of the DFO, this expertise was ignored in the department's deliberations. For example, independent Canadian scientists, including Davis, Koski, Miller, Richardson, and Ross, wrote several chapters of the 1993 monograph The Bowhead Whale, but none of them were invited to participate as experts in the DFO's assessments. Three papers (Davis and Koski, 1980; Finley, 1990; Richardson et al., 1995a) contain much of the published research on the species, yet the DFO reports contain little or no reference to them. Hutchings et al. (1997) noted that there is much variability in fisheries science and in stock assessment documents within and among different regional branches of the DFO, and that their comments and criticisms may not be wholly applicable to all regions. I believe that the problems are even more serious in the Arctic because of its remoteness from most of the Canadian public. Hutchings et al. (1997:1208) concluded that there is "a clear and immediate need for Canadians to examine very seriously the role of bureaucrats and politicians in the management of Canada's natural resources."

In 1997, a parliamentary committee was appointed to examine the problems in the DFO, and public hearings were held across Canada. Although the committee focused on the problems of the east and west coast fisheries, the issues of Arctic fisheries management and the bowhead hunt were also presented (Munro, 1998). Although the committee unanimously recommended a complete restructuring of the DFO, its recommendations were rejected (Anderssen, 1998; Thorne, 1998). After the chairman was dismissed, the vice-chairman concluded that nothing had been accomplished (Canadian Press, 1999).

At the Summit of the Sea conference held in 1997 at St. Johns, Newfoundland, Canada launched an Ocean Charter and invited other countries to sign. The Ocean Charter underlines Canada's commitment to the United Nations conventions on the Law of the Sea (1982) and on Environment and Development (UNCED, 1992). Both conventions require countries to work through the appropriate international organization for the conservation and management of whales. The UNCED agreement (Agenda 21) recognizes the responsibility of the IWC for the conservation and management of whale stocks (Simmonds and Von Bismarck, 1998).

The actions of the DFO have violated both the Oceans Act and the Ocean Charter, and they undermine international agreements for the conservation and management of whales. In the view of many of Canada's prominent whale biologists, the "prudent conservation and management of 
living resources is largely dependent on the effectiveness of international agreements. Canada's disregard for Agenda 21 and the International Convention for the Regulation of Whaling sets a poor example and devalues all such agreements" (Darling et al., 1997). President Clinton stated that "Canada's conduct jeopardizes the international effort that has allowed whale stocks to begin to recover from the devastating effects of historic whaling. International law, as reflected in the 1982 United Nations Convention on the Law of the Sea, obligates countries to work through the appropriate international organization for the conservation and management of whales. Canada has conducted whaling activities that diminish the effectiveness of a conservation program of the International Whaling Commission" (Goldberg, 1998:5). Mitchell and Reeves (1986:70) stated that "Canada's lack of participation in the IWC since 1982 has meant that it has had no voice in the international management of bowheads. We consider this circumstance unfortunate." Reeves and Heide-Jørgensen (1996:123) concluded that "[initiation] of whaling on bowheads in the eastern North American Arctic must be considered in an international context...Canada has an obligation to seek international cooperation on bowhead conservation and to subject its programs of bowhead population assessment and hunt management to independent scrutiny." One of the major recommendations of World Wildlife Fund's Arctic whales program was for Canada to rejoin the IWC (Hummel, 1986).

In response to international pressure over its whaling policies, the DFO has provided support to special interest groups such as the World Council of Whalers (Schmidt, 1999). In 1999, the WCW passed a resolution encouraging the Government of Canada to increase the harvest of bowheads in Nunavut (WCW, 1999). In 2000, the minister of the DFO granted another permit to take a bowhead from the Hudson Bay population (Weber, 2000), an action condemned by the IWC (2000a).

Although endangered whales such as the bowhead face several environmental threats, the first priority is to address the immediate, well-defined threat of overkill from hunting (Reeves, 1997). This is the only source of direct mortality that can be effectively controlled. Mitchell and Reeves (1982:74) concluded that any "removals from or disturbance to a population of this size must be regarded as a serious threat to its survival. Therefore, until bowheads can be demonstrated to have recovered to a high proportion of their initial level, no hunting of any sort should take place in the eastern Arctic." This policy must go hand in hand with efforts to protect critical habitat and to educate future resource users about the real potential for a sustainable harvest. A conservation and recovery plan will have to be a long-term vision, implemented across several human generations. Long-term recovery goals should be based solely on biological considerations, including habitat restoration and protection (Scott et al., 1995).

\section{EPILOGUE}

As noted at the outset, the Greenland whale is a species that engenders superlatives. Charles Darwin called it one of the most wonderful animals in the world. Science has shown this to be an understatement.

\section{ACKNOWLEDGEMENTS}

This paper began as a status report to the Committee on the Status of Endangered Wildlife in Canada. COSEWIC provided funding for part of the work. My family provided support in many ways. I gratefully acknowledge the comments of many colleagues and the anonymous reviewers.

\section{REFERENCES}

ANDERS, G., HALLER, A., FOOTE, D., and COVE, P. 1967. The east coast of Baffin Island: An area economic survey. Area Economic Survey Report 66/4. Ottawa: Department of Indian Affairs and Northern Development. $196 \mathrm{p}$.

ANDERSON, R.M. 1934. Mammals of the eastern Arctic and Hudson Bay. In: Bethune, W.C., ed. Canada's Eastern Arctic: Its history, resources, population and administration. Ottawa: Department of the Interior. 67-108.

ANDERSSEN, E. 1998. MPs contradict Chrétien, insist Baker was pushed from fisheries committee post. The Globe and Mail (Toronto), 2 October.

ANONYMOUS. 1874. Is whaling a declining industry? Dundee Advertiser, 24 November.

- 1977. International Whaling Commission's deletion of native exemption for the subsistence harvest of bowhead whales. Washington, D.C.: Department of Commerce, National Oceanic and Atmospheric Administration. $210 \mathrm{p}$.

1990. Igalirtuuq: A conservation proposal for bowhead whales at Isabella Bay, Baffin Island, NWT. Report in English and Inuktitut by Igalirtuuq Committee, Clyde River Hunters and Trappers Association. 19 p. + appendices and map. Available at World Wildlife Fund (Canada), 245 Eglinton Ave. E., Toronto, Ontario M4P 3J1.

ASSOCIATED PRESS. 1998. Hunt sparks bitter debate: Native revival of whale harvest needless killing, activists say. Victoria Times Colonist, 14 July.

BEDNARSKI, J. 1990. An early Holocene bowhead whale (Balaena mysticetus) in Nansen Sound, Canadian Arctic Archipelago. Arctic 43(1):50-54

BORN, E.W., and HEIDE-JØRGENSEN, M.-P. 1983. Observations of the bowhead whale (Balaena mysticetus) in central West Greenland in March-May, 1982. Report of the International Whaling Commission 33:545-547.

BRADSTREET, M.S., THOMSON, D.H., and FISSEL, D.B. 1987. Bowhead whale food availability characteristics in the southern Beaufort Sea: 1985 and 1986. Environmental Studies No. 50. Ottawa: Department of Indian Affairs and Northern Development. $359 \mathrm{p}$. 
BREMER, R. 1996. Jubilation over bowhead hunt. NewsNorth (Yellowknife), 12 February.

BRETT, C. 1999. Ice whales. A film by Survival-Anglia. London. $55 \mathrm{~min}$.

BROWN, R. 1868. Notes on the history and geographical relations of the cetacea frequenting Davis Strait and Baffin's Bay. Proceedings of the Zoological Society of London 1868: 533-556.

BROWNELL, R.L., and RALLS, K. 1986. Potential for sperm competition in baleen whales. Reports of the International Whaling Commission. Special Issue 8:110-141.

BURNS, J.J. 1993. Preface. In: Burns, J.J., Montague, J.J., and Cowles, C.J., eds. The bowhead whale. The Society for Marine Mammalogy, Special Publication No. 2. Lawrence, Kansas: Allen Press. xxiii-xxxvi.

BURNS, J.J., MONTAGUE, J.J., and COWLES, C.J., eds. 1993. The bowhead whale. The Society for Marine Mammalogy, Special Publication No. 2. Lawrence, Kansas: Allen Press. $787 \mathrm{p}$.

CAMPBELL, R.R., YURICK, D., and SNOW, D.N. 1988. Predation of narwhals (Monodon monoceros) by killer whales (Orcinus orca). Canadian Field-Naturalist 102:689-696.

CANADIAN PRESS. 1999. Fisheries panel partisan: MP. The Globe and Mail (Toronto). 9 February.

CASWELL, H., FUJIWARA, M., and BRAULT, S. 1999. Declining survival probability threatens the North Atlantic right whale. Proceedings of the National Academy of Science 96:3308-3313.

CLARK, C.W. 1991. Moving with the heard. Natural History $3: 38-42$.

CLARK, C.W., and JOHNSON, J.H. 1984. The sounds of the bowhead whale, Balaena mysticetus, during the spring migrations of 1979 and 1980. Canadian Journal of Zoology 62:1436-1441.

COSENS, S.E. 2000. Summary of research on Hudson BayFoxe Basin and Baffin Bay-Davis Strait bowhead whales. Unpubl. ms. SC 52 /OS7 to the Scientific Committee of the International Whaling Commission, Australia. Available at DFO, 501 University Crescent, Winnipeg, Manitoba R3T 2N6, Canada. $10 \mathrm{p}$.

COSENS, S.E., and BLOUW, A. 1999. Age classes of bowhead whales summering in northern Foxe Basin. Unpubl. ms. by Fisheries and Oceans Canada, Winnipeg. Canadian Stock Assessment Secretariat Research Document 99/135. Available at DFO, 501 University Crescent, Winnipeg, Manitoba R3T 2N6, Canada. 19 p.

COSENS, S.E., and INNES, S. 2000. Distribution and numbers of bowhead whales (Balaena mysticetus) in northwestern Hudson Bay in August 1995. Arctic 53(1):36-41.

COSENS, S.E., QAMUKAQ, T., PARKER, B., DUECK, L.P., and ANARDJUAK, B. 1997. The distribution and numbers of bowhead whales, Balaena mysticetus, in northern Foxe Basin in 1994. Canadian Field-Naturalist 111:381-388.

CUMMINGS, W.C., and HOLLIDAY, D.V. 1987. Sounds and source levels from bowhead whales off Pt. Barrow, Alaska. Journal of Acoustical Society of America 82:814-821.

DARLING, J., WHITEHEAD, H., BELAND, P., SEARS, R., WEILGART, L., LIEN, J., MILLER, E., and McALPINE, D.
1997. Canada and the International Whaling Commission. A letter to the Right Honourable Jean Chrétien, Prime Minister of Canada, April 3, 1997. Available at West Coast Whale Research Foundation, 1200-925 West Georgia St., Vancouver, British Columbia V6C 3L2.

DARWIN, C. 1859. On the origin of species by means of natural selection, or the preservation of favoured races in the struggle for life. London: Murray. Reprinted 1909 by Harvard Classics, C.W. Eliot (ed.), New York. 552 p.

DAVIS, R.A., and KOSKI, W.R. 1980. Recent observations of the bowhead whale in the eastern Canadian High Arctic. Report of the International Whaling Commission 30:439-444.

DAVIS, R.A., KOSKI, W.R., and MILLER, G.W. 1983. Preliminary assessment of the length-frequency distribution and gross annual reproductive rate of the Western Arctic bowhead whale as determined with low-level aerial photography, with comments on life history. Unpubl. ms. by LGL Ltd., Toronto, for National Marine Mammal (NMM) Lab, Seattle, Washington. Available at NMM Lab, 7600 Sand Point Way, Seattle, Washington 98115. U.S.A. 91 p.

1986. Experimental use of aerial photogrammetry to assess the long-term responses of bowhead whales to offshore industrial activities in the Canadian Beaufort Sea, 1984. Environmental Studies No. 44. Ottawa: Department of Indian and Northern Affairs. $157 \mathrm{p}$.

DFO (DEPARTMENT OF FISHERIES AND OCEANS). 1979. Whaling regulations made under the Whaling Convention Act (Amendment list 1). Department of Fisheries and Oceans, Departmental Manual of Acts and Regulations 24:1-4.

. 1996a. Report of the National Marine Mammal Peer Review Committee. Unpubl. ms. to Arctic Fisheries Scientific Advisory Committee, Fisheries and Oceans, Winnipeg, Manitoba, February 7-8. Available at DFO, 501 University Crescent, Winnipeg, Manitoba R3T 2N6, Canada.

1996b. Eastern Arctic bowhead whales (1996 update). Unpubl. ms. of the Arctic Fisheries Scientific Advisory Committee, Fisheries and Oceans, Ottawa. 26 p.

. 1998. Canada's Oceans Act. Pamphlet by Communications Directorate, Department of Fisheries and Oceans Canada, Ottawa. . 1999a. Proceedings of the RAP meeting on Hudson Bay/ Foxe Basin bowhead. Iqaluit, Nunavut, 17-18 June 1999. Unpubl. ms. by Fisheries and Oceans, Winnipeg. Canadian Stock Assessment Proceedings Series 99/23. Available at DFO, 501 University Crescent, Winnipeg, Manitoba R3T 2N6, Canada. 22 p.

. 1999b. Hudson Bay-Foxe Basin bowhead whales. Unpubl. ms. by Fisheries and Oceans, Winnipeg. Stock status report E552. Available at DFO, 501 University Crescent, Winnipeg, Manitoba R3T 2N6, Canada. 8 p.

DIAND (DEPARTMENT OF INDIAN AFFAIRS AND NORTHERN DEVELOPMENT). 1993. Agreement between the Inuit of the Nunavut settlement area and her majesty the Queen in right of Canada. Ottawa: DIAND and Tungavik. $282 \mathrm{p}$.

DURHAM, F.E. 1974. Ancient and current methods of taking the bowhead whale. Alaska Sea Grant Report No 73-9. Anchorage: University of Alaska. $15 \mathrm{p}$ 
DYKE, A.S., and MORRIS, T.F. 1990. Postglacial history of the bowhead whale and of driftwood penetration: Implications for paleoclimate, Central Canadian Arctic. Geological Survey of Canada Paper 89-24:1-17.

EDWARDS, R. 1998. The price of arrogance. New Scientist (London), 17 October.

ESCHRICHT, D.F., and REINHARDT, J. 1866. On the Greenland right-whale (Balaena mysticetus, Linn.), with especial reference to its geographic distribution and migrations in times past and present, and to its external and internal characteristics. Published for Ray Society by Robert Hardwick, London. 150 p.

EVERITT, R.D., and KROGMAN, B.D. 1979. Sexual behavior of bowhead whales observed off the north coast of Alaska. Arctic 32(3):277-280.

FERGUSON, M.A.D., WILLIAMSON, R.G., and MESSIER, F. 1998. Inuit knowledge of long-term changes in a population of Arctic tundra caribou. Arctic 51(1):201-219.

FINDLAY, K.P. 1997. A review of the effects of tourism activities on cetaceans. Report SC/49/29 to the Scientific Committee. Report of the International Whaling Commission 48.

FINLEY, K.J. 1990. Isabella Bay, Baffin Island: An important historical and present-day concentration area for the endangered bowhead whale (Balaena mysticetus) of the eastern Canadian Arctic. Arctic 43(2):137-152.

- 1991. Review of "Whaling communities," edited by E. Vestergaard. Arctic 44(2):167-168.

__ 1998. Observations of bowhead whales at Isabella Bay, Baffin Island, 1983-1997. Unpubl. ms. SC 50 /AS 15 to the Scientific Committee of the International Whaling Commission, Oman. Available at International Whaling Commission, 135 Station Road, Histon, Cambridge CB4 4NP, United Kingdom. 9 p.

- 2000. Status of the Greenland Whale, or bowhead, in the Northwest Atlantic. Unpubl. ms. SC 52/AS to the Scientific Committee of the International Whaling Commission, Adelaide, Australia. Available at International Whaling Commission, 135 Station Road, Histon, Cambridge CB4 4NP, United Kingdom. $29 \mathrm{p}$.

FINLEY, K.J., and DARLING, L.M. 1990. Historical data sources on the morphometry and oil yield of the bowhead whale. Arctic 43(2): $153-156$.

FINLEY, K.J., and MILLER, G.W. 1982. The 1979 hunt for narwhals (Monodon monoceros) and an examination of harpoon gun technology near Pond Inlet, northern Baffin Island. Report of the International Whaling Commission 32:449-460.

FINLEY, K.J., MILLER, G.W., ALLARD, M., DAVIS, R.A., and EVANS, C.R. 1982. The belugas (Delphinapterus leucas) of northern Quebec: Distribution, abundance, stock identity, catch history, and management. Canadian Technical Report of Fisheries and Aquatic Sciences No. 1123. 57 p.

FINLEY, K.J., EVANS, C.R., and DAVIS, R.A. 1983. Evaluation of the importance of Isabella Bay, Baffin Island, as summer habitat for the endangered bowhead whale. Progress report of 1983 studies. Unpubl.ms available at WorldWildlife Fund(Canada), 245 Eglinton Ave. E., Toronto, Ontario M4P 3J1. 72 p.

. 1984. Evaluation of the importance of Isabella Bay, Baffin Island, as summer habitat for the endangered bowhead whale.
Progress report of 1984 studies. Unpubl. ms available at World Wildlife Fund (Canada), 245 Eglinton Ave. E., Toronto, Ontario M4P 3J1. 30 p.

FINLEY, K.J., MILLER, G.W., DAVIS, R.A., and GREENE, C.R. 1990. Reactions of belugas and narwhals to ice-breaking ships in the Canadian High Arctic. In: Smith, T.G., St. Aubin, D.J., and Geraci, J.R., eds. Advances in research on the beluga whale, Delphinapterus leucas. Canadian Journal of Fisheries and Aquatic Science Bulletin No. 224. 97-117.

FINLEY, K.J., FISSEL, D.B., GOODYEAR, J.D., and ASHTON, H.J. 1993. Definition of critical bowhead whale feeding habitat in Baffin Bay, 1992. Unpubl. ms. to Supply and Services Canada, Environment Canada, World Wildlife Fund, and Indian Affairs and Northern Development, Ottawa, Ontario, Canada. Available at World Wildlife Fund (Canada), 245 Eglinton Ave. E., Toronto, Ontario M4P 3J1. 100 p.

FOLEY,P. 1997. Metapopulation processes: Extinction models for local populations. In: Hanski, I.A., and Gilpin, M., eds. Metapopulation biology: Ecology, genetics and evolution. San Diego: Academic Press. 215-242.

FREEMAN, M.M.R. 1990. A commentary on political issues with regard to contemporary whaling. In: Vestergaard, E., ed. Whaling communities. North Atlantic Studies Vol. 2. Aarhus, Denmark: Aarhus University Press. 106-116.

1996. Bowhead whales recovering? International Network for Whaling Research Number 11. Edmonton: Canadian Circumpolar Institute, University of Alberta. 4 p.

GAMBELL, R. 1993. International management of whales and whaling: An historical review of the regulation of commercial and aboriginal subsistence whaling. Arctic 46(2):97-107.

GEORGE, J.C., CLARKE, C., CARROLL, G.M., and ELLISON, W.T. 1989. Observations on the ice-breaking and ice navigation behavior of migrating bowhead whales (Balaena mysticetus) near Point Barrow, Alaska, spring 1985. Arctic 42(1):24-30.

GEORGE, J.C., PHILO, L.M., HAZARD, K., WITHROW, D., CARROLL, G.M., and SUYDAM, R. 1994. Frequency of killer whale (Orcinus orca) attacks and ship collisions based on scarring on bowhead whales (Balaena mysticetus) of the BeringChukchi-Beaufort Seas stock. Arctic 47(3):247-255.

GEORGE, J.C., BADA, J., ZEH, J., SCOTT, J.L., BROWN, S.E., O'HARA, T., and SUYDAM, R. 1999. Age and growth estimates of bowhead whales (Balaena mysticetus) via aspartic acid racemization. Canadian Journal of Zoology 77:571-580.

GERBER, L.R., and DeMASTER, D.P. 1999. A quantitative approach to endangered species act classification of long-lived vertebrates: Application to the North Pacific humpback whale. Conservation Biology 13:1203-1214.

GIBB, D. 1837. Narrative of the sufferings of the crew of the Dee, while beset in the ice at Davis' Straits, during the winter of 1836. Aberdeen: Clark and Son. Reprinted in Troup, J.A., ed. 1987. The ice-bound whalers: The story of the Dee and the Grenville Bay, 1836-37. Kirkwall: The Orkney Press and Stromness Museum. 129 p.

GOLDBERG, K. 1998. Canada and the International Whaling Commission. Canadian Marine Mammal Journal 3:3-7.

GOODYEAR, J.D. 1996. Significance of feeding habitats of North Atlantic right whales based on studies of the diel behaviour, 
diving, food ingestion rates, and prey. Unpubl. Ph.D. Thesis. University of Guelph, Ontario. 269 p.

GRAY, R.W. 1888. Whale fisheries. Encyclopaedia Britannica.9th ed. 24:526-528.

. 1926. The Peterhead whalers: Memories of a bygone adventure. The Buchan Observer, Peterhead, Scotland. Part 5. December 28, 1926. Peterhead Library MS 9504.

_ 1927. The Peterhead whalers: Memories of a bygone adventure. The Buchan Observer, Peterhead, Scotland. Part 6. January 4, 1927. Peterhead Library MS 9504.

- 1932. Peterhead sealers and whalers: A contribution to the history of the whaling industry. The Scottish Naturalist. Peterhead Library MS Ab75T39

GREGOIRE, L. 1994a. Will bowhead hunting return to Nunavut? Special Report on Nunavut. Nunatsiaq News (Iqaluit), 5 April. 1994b. Bowhead killed for the love of an elder: NWMB responds to illegal bowhead hunt. Nunatsiaq News (Iqaluit), 23 September.

GRIFFITHS, W.B., THOMPSON, D.H., and JOHNSON, G.E. 1987. Zooplankton and hydroacoustics. In: Richardson, W.J., ed. Importance of the eastern Alaskan Beaufort Sea to feeding bowhead whales, 1985-86. Unpubl. report by LGL Ltd. for U.S. Minerals Management Service, Reston, Virginia 22091, U.S.A. NTIS PB88-150271. 167-323.

GUERIN, A.H. 1845. On the rock-nose of the whaler, a variety of the Balaena mysticetus. Edinburgh New Philosophical Journal 39:266-269.

HEIDE-JØRGENSEN, M.P., andFINLEY, K.J. 1991. Photographic reidentification of a bowhead whale in Davis Strait. Arctic 44(3):254-256.

HOLST, M., and STIRLING, I. 1999. Sightings of bowhead whales in the North Water polynya, northern Baffin Bay, in May-June, 1998. Journal of Cetacean Research and Management 1:153-156.

HOUSTON, J., and CAMPBELL, R. 1996. Updated report on the status of the bowhead whale, Balaena mysticetus, in Canada. Report to the Committee on the Status of Endangered Wildlife in Canada, Fish and Marine Mammals Subcommittee. Ottawa: Canadian Wildlife Service. 140 p.

HUMMEL, M. 1986. Whales beneath the ice: Final report, conclusions and recommendations regarding the future of Canada's Arctic whales. Available at World Wildlife Fund (Canada), 245 Eglinton Ave. E., Toronto, Ontario M4P 3J1. $40 \mathrm{p}$.

HUNTINGTON, H.P. 1999. Traditional knowledge of the ecology of beluga whales (Delphinapterus leucas) in the eastern Chukchi and northern Bering Seas, Alaska. Arctic 52(1):49-61.

HUTCHINGS, J.A., WALTERS, C., and HAEDRICH, R.L. 1997. Is scientific inquiry incompatible with government information control? Canadian Journal of Fisheries and Aquatic Sciences 54:1198-1210.

INNES, S. 1996. Population viability analysis for bowhead whales (Balaena mysticetus) in the Nunavut settlement area. Unpubl. ms. Available at DFO, 501 University Crescent, Winnipeg, Manitoba R3T 2N6. 15 p.

INNOVA. 1994. Natural science meets social science in Canada's North. Innova, Canada's Environmental Innovation Program.
Ottawa: Public Works and Government Services Canada. Spring 1994. 28 p.

IWC (INTERNATIONAL WHALING COMMISSION). 1982. Report of the sub-committee on protected species and aboriginal whaling. Report of the Scientific Committee. 32nd Report of the International Whaling Commission 32:104-112.

. 1992. Report of the Scientific Committee, Annex E (Bowhead whale assessment meeting). 42nd Report of the International Whaling Commission 42:137-151.

- 1996. Report of the Scientific Committee. Appendix 12. Resolution on Canadian whaling. Report of the International Whaling Commission 46.

1998. Report of the Scientific Committee. 48th Report of the International Whaling Commission.

1999. Report of the Scientific Committee. Agenda Item 18.1. Resolution on small populations of highly endangered whales. Report of the International Whaling Commission 51.

. 2000a. Resolution on whaling of highly endangered bowhead whales in the eastern Canadian Arctic. IWC/52/38. Agenda item 10.3.2

- 2000b. Report of the Scientific Committee. Report of the workshop on status and trends of western North Atlantic right whales. Report SC/52/1 presented to the Scientific Committee, Adelaide, Australia. $31 \mathrm{p}$.

JACOBS, J.D., BARRY, R.G., BRADLEY R.S., and WEAVER, R.L. 1974. Studies of climate and ice conditions in eastern Baffin Island, 1971 - 1973. Boulder, Colorado: Institute of Arctic and Alpine Research Occasional Paper 9. 78 p.

JOHNSON, L. 1994. Pattern and process in ecological systems: A step in the development of an ecological theory. Canadian Journal of Fisheries and Aquatic Science 51:226-246.

- 2000. Imperfect symmetry: Action principles in ecology and evolution. In: Jorgenson, S.E., ed. Thermodynamics and ecological modelling. Boca Raton, Florida: Lewis. 231-285.

JONSGÅRD, A. 1981. Bowhead whales, Balaena mysticetus, observed in Arctic waters of the eastern North Atlantic after the Second World War. Report of the International Whaling Commission 31:511.

1982. Bowhead (Balaena mysticetus) surveys in Arctic Northeast Atlantic waters in 1980. Report of the International Whaling Commission 32:355-356.

KAPEL, F.O. 1985. A note on the net entanglement of a bowhead whale (Balaena mysticetus) in Northwest Greenland, November 1980. Report of the International Whaling Commission 35:377-378.

KELLERT, S.R. 1985. Social and perceptual factors in endangered species management. Journal of Wildlife Management 49:528-536.

KENNEY, R.D. 1997. North Atlantic right whales and the El NiñoSouthern Oscillation Cycle: Implications of global climate change for the conservation of an endangered whale species. Abstract. 11th Annual Meeting of the Society for Conservation Biology, 6-9 June 1997, Victoria, B.C.

1998. Global climate change and whales: Western North Atlantic right whale calving rate correlates with the Southern Oscillation Index. Paper SC/M98/RW29. Report of the workshop on the comprehensive assessment of right whales: A worldwide 
comparison. Report of the International Whaling Commission 50. $45 \mathrm{p}$. and appendices.

KNOWLTON, A.R., KRAUS, S.D., and KENNEY, R.D. 1994. Reproduction in North Atlantic right whales (Eubalaena glacialis). Canadian Journal of Zoology 72:1297-1305.

KOSKI, W.R., DAVIS, R.A., MILLER, G.W., and WITHROW, D.W. 1992. Growth rates of bowheads as determined from lowlevel aerial photogrammetry. Report of the International Whaling Commission 42:491-499.

. 1993. Reproduction. In: Burns, J.J., Montague, J.J., and Cowles, C.J., eds. The bowhead whale. The Society for Marine Mammalogy, Special Publication No. 2. Lawrence, Kansas: Allen Press. 239-274.

KRAUS, S.D. 1990. Rates and potential causes of mortality in North Atlantic right whales (Eubalaena glacialis). Marine Mammal Science 6:278-291.

KRAUS, S.D., HAMILTON, P., KENNEY, R., KNOWLTON, A., and SLAY, C. In press. Reproductive parameters of the North Atlantic right whale. Journal of Cetacean Research and Management. Special Issue 2.

KRUTZIKOWSKY, G.K., and MATE, B. 2000. Dive and surfacing characteristics of bowhead whales (Balaena mysticetus) in the Beaufort and Chukchi Seas. Canadian Journal of Zoology 78:1182-1198.

LACY, R.C., and KREEGER, T. 1992. VORTEX User's Manual. Chicago: Chicago Zoological Society.

LAGHI, B. 1998. Whales caught in clash of cultures: Scientists say bowheads in danger; Inuit see kill as symbol of sovereignty. The Globe and Mail (Toronto), 30 April.

LGL Ltd. 1983. Biological environment of eastern Lancaster Sound and western Baffin Bay: Components and important processes. Environmental Studies No. 30. Ottawa: Department of Indian and Northern Affairs. 288 p.

- 1986. Proposal for continuing studies of the eastern Arctic bowhead whale at Isabella Bay, Baffin Island. Available at World Wildlife Fund (Canada), 245 Eglinton Avenue E., Toronto, Ontario M4P 3J1. 25 p.

LOWRY, L. 1993. Foods and feeding ecology. In: Burns, J.J., Montague, J.J., and Cowles, C.J., eds. The bowhead whale. The Society for Marine Mammalogy, Special Publication No. 2. Lawrence, Kansas: Allen Press. 201-239.

LUBBOCK, B. 1937. The Arctic whalers. Glasgow: Brown, Son and Ferguson, Ltd. 483 p.

MacARTHUR, R.H., and WILSON, E.O. 1967. The theory of island biogeography. Princeton: Princeton University Press. 203 p.

MAIERS, L.D., DE MARCH, B.G., CLAYTON, J.W., DUECK, L.P., and COSENS, S.E. 1999. Genetic variation among populations of bowhead whales summering in Canadian waters. Unpubl. ms. by Fisheries and Oceans Canada, Winnipeg, Manitoba R3T 2N6, Canada. 24 p.

MANSFIELD, A.W. 1985. Status of the bowhead whale, Balaena mysticetus, in Canada. Canadian Field-Naturalist 99:421 -424.

MATE, B.R., KRUTZIKOWSKY, G.K., and WINSOR, M.H. 2000. Satellite-monitored movements of radio-tagged bowhead whales in the Beaufort and Chukchi Seas during the late-summer feeding season and fall migration. Canadian Journal of Zoology 78:1168-1181.
MAXWELL, J.B. 1982. The climate of the Canadian Arctic Islands and adjacent waters, Vol. 2. Climatology Studies 30. Ottawa: Canadian Government Publishing Centre. 493 p.

MAYO, C.A., and MARX, M.K. 1994. Surface foraging behavior of the North Atlantic right whale, Eubalaena glacialis, and associated zooplankton characteristics. Canadian Journal of Zoology 68:2214-2220.

McCARTNEY, A.P., and SAVELLE, J.M. 1985. Thule Eskimo whaling in the central Canadian Arctic. Arctic Anthropology 22:37-58.

1993. Bowhead whale bones and Thule Eskimo subsistencesettlement patterns in the central Canadian Arctic. Polar Record 29:1-12.

McGOVERN, T.H. 1980. Cows, harp seals, and churchbells: Adaptation and extinction in Norse Greenland. Human Ecology 8:245-275.

McILROY, A. 1999a. Incentives proposed to protect animals. The Globe and Mail (Toronto), 17 December.

- 1999b. Ottawa's endangered species plan called inadequate. The Globe and Mail (Toronto), 18 December.

- 1999c. Minister, green groups lock horns over endangered species. The Globe and Mail (Toronto), 27 December.

- 2000a. Ottawa gets tough to save at-risk species. The Globe and Mail (Toronto), 11 April.

-2000b. Species legislation too weak to prevent extinction, groups say. The Globe and Mail (Toronto), 12 April.

McLAREN MAREX INC. 1979. Report on aerial surveys of birds and marine mammals in the southern Davis Strait between April and December 1978. Unpubl. ms. by McLaren Marex Inc., Dartmouth for Esso Resources Canada. Arctic Petroleum Operators Association Project No. 146. Volume 3: Marine mammals. Available at AINA Library, University of Calgary, Calgary, Alberta T2N 1N4, Canada.

McLAREN, P.L., and DAVIS, R.A. 1981. Distribution of wintering marine mammals in southern Baffin Bay and northern Davis Strait, March 1981. Unpubl. ms. by LGL Ltd., Toronto, for Arctic Pilot Project, Petro-Canada Explorations Inc., Calgary. Available at AINA Library, University of Calgary, Calgary, Alberta T2N 1N4, Canada. 85 p.

_ 1983. Distribution of wintering marine mammals off West Greenland and in southern Baffin Bay and northern Davis Strait, March 1982. Unpubl. ms. by LGL Ltd., Toronto, for Arctic Pilot Project, Petro-Canada Explorations Inc., Calgary. Available at AINA Library, University of Calgary, Calgary, Alberta T2N 1N4, Canada. 98 p.

McLEOD, S.A., WHITMORE, F.C., and BARNES, L.G. 1993. Evolutionary relationships and classification. In: Burns, J.J., Montague, J.J., and Cowles, C.J., eds. The bowhead whale. The Society for Marine Mammalogy, Special Publication No. 2. Lawrence, Kansas: Allen Press. 45-70.

MELVILLE, H. 1851. Moby Dick or the white whale. Reprint. New York: Signet Classic. 543 p.

MITCHELL, E.D., and REEVES, R.R. 1980. The Alaska bowhead problem: A commentary. Arctic 33(4):686-723.

. 1981. Catch history and cumulative catch estimates of initial population size of cetaceans in the eastern Canadian Arctic. Report of the International Whaling Commission 31:645-682. 
1982. Factors affecting abundance of bowhead whales, Balaena mysticetus, in the eastern Arctic of North America, 1915-1980. Biological Conservation 22:59-78.

1986. Current status of the Bering Sea stock of bowhead whales. Muskox 34:1-20.

MITCHELL, E., REEVES, R.R., EVELY, A., and STAWSKI, M. 1986. Bibliography of whale killing techniques. Reports of the International Whaling Commission. Special Issue \#8. 161 p.

MONTAGUE, J.J. 1993. Introduction. In: Burns, J.J., Montague, J.J., and Cowles, C.J., eds. The bowhead whale. The Society for Marine Mammalogy, Special Publication No. 2. Lawrence, Kansas: Allen Press. 1-21.

MOORE, S.E., and REEVES, R.R. 1993. Distribution and movement. In: Burns, J.J., Montague, J.J., and Cowles, C.J., eds. The bowhead whale. The Society for Marine Mammalogy, Special Publication No. 2. Lawrence, Kansas: Allen Press. 313-386.

MUNRO, M. 1998. Whale of a dilemma in the Arctic. The Vancouver Sun, 21 January.

MYERS, H. 1990. Community conservation planning in action: Protecting the bowhead whales at Isabella Bay. Arctic Institute of North America, Information North 15:16.

NERINI, M.K., BRAHAM, H.W., MARQUETTE, W.M., and RUGH, D.J. 1984. Life history of the bowhead whale, Balaena mysticetus (Mammalia: Cetacea). Journal of Zoology 204:443-468.

NICKLIN, F. 1991. Life at the edge: Beneath Arctic ice. National Geographic 180:2-31.

- 1995. Bowhead whales: Leviathans of icy seas. National Geographic 188:114-129.

NWMB (NUNAVUT WILDLIFE MANAGEMENT BOARD). 2000. Final report of the Inuit bowhead knowledge study. Iqaluit: Nunavut Wildlife Management Board. 90 p.

ØEN, E.O. 1995. A new penthrite grenade compared to the traditional black powder grenade: Effectiveness in the Alaskan Eskimo's hunt for bowhead whales. Arctic 48(2):177-185.

O'HARA, T., HOUSE, C., HOUSE, J.A., SUYDAM, R.S., and GEORGE, J.C. 1998. Viral serologic survey of bowhead whales in Alaska. Journal of Wildlife Diseases 34:39-46.

O'HARA, T.M., KRAHN, M.M., BOYD, D., BECKER, P.R., and PHILO, L.M. 1999. Organochlorine contaminant levels in Eskimo harvested bowhead whales of Arctic Alaska. Journal of Wildlife Diseases 35:741-752.

PAIN, S. 1987. Age miscalculations threaten bowhead whales. New Scientist, March, 1987:21.

PARKINSON, C.L. 2000. Variability of Arctic sea ice: The view from Space, an 18-year record. Arctic 53(4):341-358.

PAYNE, R.S. 1995. Among whales. New York: Scribner. 431 p. PHILIPS, T. 1995. Four U.S. tourists die on ill-fated trip-wanted picture of whale. Nunatsiaq News (Iqaluit), 8 September.

PHILO, L.M., SHOTTS, E.B., and GEORGE, J.C. 1993. Morbidity and mortality. In: Burns, J.J., Montague, J.J., and Cowles, C.J., eds. The bowhead whale. The Society for Marine Mammalogy, Special Publication No. 2. Lawrence, Kansas: Allen Press. 275-312.

RAFTERY, A.E., and ZEH, J.E. 1998. Estimating bowhead whale population size and rate of increase from the 1993 census. Journal of the American Statistical Association 93. 13 p.
REED, D., GENTILI, M., and PRICE, R. 1998. Bay of the Giants. Documentary film by Wildlife Associates, Dunedin, New Zealand, for Discovery Channel. $52 \mathrm{~min}$.

REEVES, R.R. 1997. Reflections on conservation priorities for endangered cetaceans. Abstract. Society for Conservation Biology. 6-9 June, Victoria, B.C.

REEVES, R.R., and HEIDE-JØRGENSEN, M.P. 1996. Recent status of bowhead whales, Balaena mysticetus, in the wintering grounds off West Greenland. Polar Research 15:115-125.

REEVES, R.R., and MITCHELL, E. 1988. Distribution and seasonality of killer whales in the eastern Canadian Arctic. Rit Fiskideildar 11:136-160.

. 1990. Bowhead whales in Hudson Bay, Hudson Strait and Foxe Basin: A review. Naturaliste Canadienne 117:25-43.

REEVES, R.E., MITCHELL, E., MANSFIELD, A., and McLAUGHLIN, M. 1983. Distribution and migration of the bowhead whale, Balaena mysticetus, in the eastern North American Arctic. Arctic 36(1):5-64.

RICHARD, P.R., ORR, J.R., DIETZ, R., and DUECK, L. 1998. Sightings of belugas and other marine mammals in the North Water, late March 1993. Arctic 51(1):1-4.

RICHARDSON, W.J., and MALME, C.I. 1993. Man-made noise and behavioral responses. In: Burns, J.J., Montague, J.J., and Cowles, C.J., eds. The bowhead whale. The Society for Marine Mammalogy, Special Publication No. 2. Lawrence, Kansas: Allen Press. 631-700.

RICHARDSON, W.J., FRAKER, M.A., WÜRSIG, B., and WELLS, R.S. 1985. Behavior of bowhead whales Balaena mysticetus summering in the Beaufort Sea: Reactions to industrial activities. Biological Conservation 32:195-230.

RICHARDSON, W.J., DAVIS, R.A., EVANS, C.R., LJUNGBLAD, D.K., and NORTON, P. 1987. Summer distribution of bowhead whales, Balaena mysticetus, relative to oil industry activities in the Canadian Beaufort Sea, 198084. Arctic 40(2):93-104.

RICHARDSON, W.J., FINLEY, K.J., MILLER, G.W., DAVIS, R.A., and KOSKI, W.R. 1995a. Feeding, social and migration behavior of bowhead whales, Balaena mysticetus, in Baffin Bay vs. the Beaufort Sea-regions with different amounts of human activity. Marine Mammal Science 11:1-45.

RICHARDSON,W.J., GREENE, C.R., MALME, C.I., and THOMPSON, D.H. 1995b. Marine mammals and noise. San Diego: Academic Press. 576 p.

ROSS, W.G. 1975. Whaling and Eskimos: Hudson Bay 1860-1915. Publications in Ethnology 10. Ottawa: National Museums of Canada. 164 p.

. 1979. The annual catch of Greenland (bowhead) whales in waters north of Canada 1717-1915: A preliminary compilation. Arctic 32(2):91-121.

1985. Arctic whalers, icy seas: Narratives of the Davis Strait whale fishery. Toronto: Irwin Publishing. 263 p.

1993. Commercial whaling in the North Atlantic sector. In: Burns, J.J., Montague, J.J., and Cowles, C.J. eds. The bowhead whale. Society for Marine Mammalogy, Special Publication No. 2. Lawrence, Kansas: Allen Press. 511-561.

RUGH, D.J., MILLER, G.W., WITHROW, D.E., and KOSKI, W.R. 1992. Calving intervals of bowhead whales established 
through photographic identifications. Journal of Mammalogy 73:487-490.

SAVELLE, J.M., and McCARTNEY, A.P. 1990. Prehistoric Thule Eskimo whaling in the Canadian Arctic Islands: Current knowledge and future research directions. In: Harington, C.R., ed. Canada's missing dimension: Science and history in the Canadian Arctic Islands. Ottawa: National Museum of Natural Sciences. 695-723.

- 1991. Thule Eskimo subsistence and bowhead whale procurement. In: Stiner, M.C., ed. Human predators and prey mortality. Boulder: Westview Press. 201-216.

SCHELL, D.M., and SAUPE, S.M. 1993. Feeding and growth as indicated by stable isotopes. In: Burns, J.J., Montague, J.J., and Cowles, C.J., eds. The bowhead whale. The Society for Marine Mammalogy, Special Publication No. 2. Lawrence, Kansas: Allen Press. 491-509.

SCHELL, D.M., SAUPE, S.M., and HAUBENSTOCK, N. 1989. Natural isotope abundances in bowhead whale (Balaena mysticetus) baleen: Markers of aging and habitat usage. In: Rundel, P., Ehleringer, J., and Nagy, K., eds. Stable isotopes in ecological research. Ecological Studies 68. 260-269.

SCHLEDERMANN, P. 1976. The effect of climatic/ecological changes on the style of Thule culture winter dwellings. Arctic and Alpine Research 8:37-47.

. 1996. Voices in stone: A personal journey into the Arctic past. Komatik Series 5. Calgary: Arctic Institute of North America. 221 p.

SCHMIDT, S. 1999. Whaling lobby gets federal cash, PR assistance. The Globe and Mail (Toronto), 14 June.

SCORESBY, W., Jr. 1820. An account of Arctic regions, with a history and description of the northern whale-fishery. Vol. 2. Edinburgh: Constable and Co. (David and Charles Reprints, Newton Abbot, Devon, England, 1969). 574 p.

SCOTT, J.M., TEAR, T.H., and MILLS, L.S. 1995. Socioeconomics and the recovery of endangered species: Biological assessment in a political world. Conservation Biology 9:214-216.

SCUDDER, G. 2000. Our wildlife are on life support. The Globe and Mail (Toronto), 19 February.

SIMMONDS, M.P., and VON BISMARCK, A. 1998. Recent important developments in the marine environment. Report SC/ 50/E7 of the Scientific Committee, 50th Meeting of the International Whaling Commission, Oman. 5 p.

THORNE, S. 1998. Ottawa tosses back fishery-committee report. The Globe and Mail (Toronto), 23 September.

TYNAN, C.T., and DeMASTER, D.P. 1997. Observations and predictions of Arctic climate change: Potential effects on marine mammals. Arctic 50(4):308-322.

UNESCO. 1994. Progress on the Igalirtuuq Biosphere Reserve Proposal for Isabella Bay. Biosphere reserves in Canada 5:1-3.

USHER, P.J. 2000. Traditional ecological knowledge in environmental assessment and management. Arctic 53(2): $183-193$.
VIBE, C. 1967. Arctic animals in relation to climatic fluctuations. Meddelelser om Grønland 170. 227 p.

VLESSIDES, M. 1998. License to whale. Canadian Geographic (January-February) 118:25-36.

WADE, P.R. 1998. Calculating limits to the allowable humancaused mortality of cetaceans and pinnipeds. Marine Mammal Science 14:1-14.

WANG, J., MYSAK, L.A., and INGRAM, R.G. 1994. Interannual variability of sea-ice cover in the Hudson Bay, Baffin Bay and Labrador Sea. Atmosphere Ocean 32:421-447.

WARTZOK, D., WATKINS, W.A., WÜRSIG, B., and MALME, C.I. 1989. Movements and behavior of bowhead whales in response to repeated exposures to noise associated with industrial activities in the Beaufort Sea. Unpubl. ms. from Purdue University to Amoco Production Company, Box 800, Denver, Colorado 80201. 228 p.

WEBER, B. 1999. Whale sanctuary beached by bureaucratic dispute. The Globe and Mail (Toronto), 18 January.

- 2000. Inuits ask to stage whale hunt. Nunatsiaq News (Iqaluit), 19 March.

WINSOR, H. 2000. The risks of tabling environment legislation. The Globe and Mail (Toronto), 3 April.

WOODBY, D.A., and BOTKIN, D.B. 1993. Stock sizes prior to commercial whaling. In: Burns, J.J., Montague, J.J., and Cowles, C.J., eds. The bowhead whale. The Society for Marine Mammalogy, Special Publication No. 2. Lawrence, Kansas: Allen Press. 387-407.

WCW (WORLD COUNCIL OF WHALERS). 1999. Resolution concerning the Nunavut bowhead hunt. March 27-30, 1999. Reykjavik, Iceland.

WÜRSIG, B., and CLARK, C.W. 1993. Behavior. In: Burns, J.J., Montague, J.J., and Cowles, C.J., eds. The bowhead whale. The Society for Marine Mammalogy, Special Publication No. 2. Lawrence, Kansas: Allen Press. 157-199.

WÜRSIG, B., DORSEY, E.M., FRAKER, M.A., PAYNE, R.S., and RICHARDSON, W.J. 1985. Behavior of bowhead whales, Balaena mysticetus, summering in the Beaufort Sea: A description. U.S. Fishery Bulletin 83:357-377.

WWF (WORLD WILDLIFE FUND). 1987. The bowhead and the bay: A community-based conservation strategy for Isabella Bay. Unpubl. ms. Available at WWF (Canada), 245 Eglinton Ave. E., Toronto, Ontario M4P 3J1. 11 p.

2000. Igaliqtuuq: A sanctuary for bowhead whales. Working for Wildlife. Winter 2000/2001. Available at WWF (Canada), 245 Eglinton Ave. E., Toronto, Ontario M4P 3J1.

ZEH, J.E., CLARK, C.W., GEORGE, J.C., WITHROW, D., CARROLL, G.M., and KOSKI, W.R. 1993. Current population size and dynamics. In: Burns, J.J., Montague, J.J., and Cowles, C.J., eds. The bowhead whale. The Society for Marine Mammalogy, Special Publication No. 2. Lawrence, Kansas: Allen Press. 409-489. 